\title{
Certification Framework
}

\section{Leakage Risk Assessment for a Potential $\mathrm{CO}_{2}$ Storage Project in Saskatchewan, Canada}

\author{
James E. Houseworth ${ }^{1}$, Curtis M. Oldenburg ${ }^{1}$, \\ Alberto Mazzoldi ${ }^{1}$, Abhishek K. Gupta ${ }^{3}$, \\ Jean-Philippe Nicot ${ }^{2}$, and Steven L. Bryant ${ }^{3}$, \\ ${ }^{1}$ Lawrence Berkeley National Laboratory, Earth Sciences Division, 90-1116 \\ Berkeley CA 94720 \\ jehouseworth@lbl.gov \\ cmoldenburg@lbl.gov \\ amazzoldi@lbl.gov \\ ${ }^{2}$ Bureau of Economic Geology, University of Texas, University Station, Box X \\ Austin, Texas 78713-8924 \\ jp.nicot@beg.utexas.edu \\ ${ }^{3}$ CPGE, University of Texas, Austin, 1 University Station C0300 \\ Austin, TX 78712-0228 \\ abhishek.k.gupta@mail.utexas.edu \\ steven_bryant@mail.utexas.edu
}

\section{May 11, 2011}

Acknowledgments: We thank Preston Jordon for providing a careful review of this report. This work was supported in part by the Petroleum Technology Research Centre, Regina, Saskatchewan, Canada, and by Lawrence Berkeley National Laboratory under Department of Energy Contract No. DE-AC02-05CH11231. Additional support comes from the University of Texas, Austin, and the Bureau of Economic Geology, University of Texas. 
This page left intentionally blank. 
Table of Contents

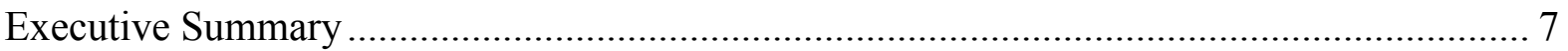

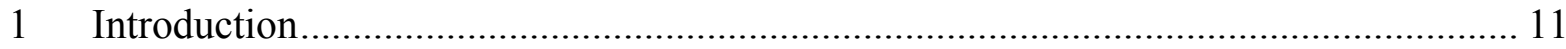

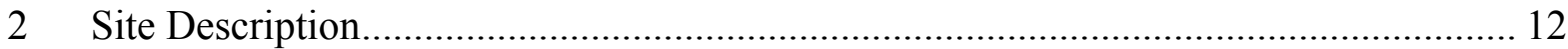

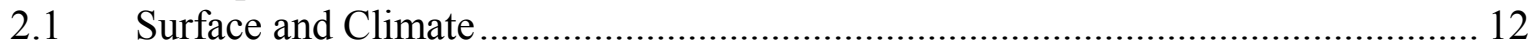

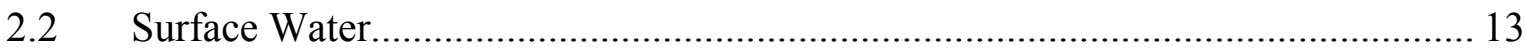

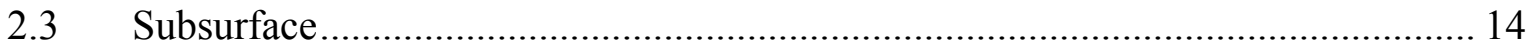

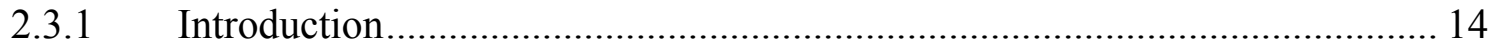

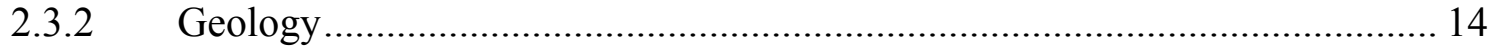

2.3.3 Subsurface Hydrology ……………….................................................... 16

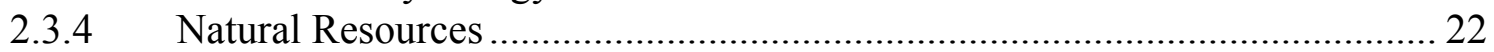

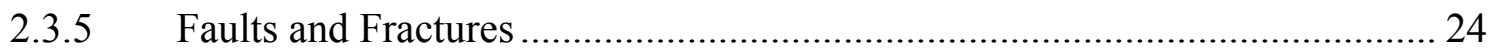

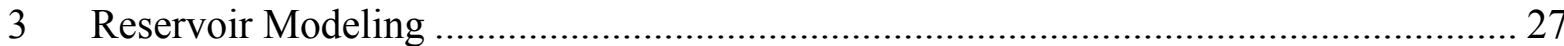

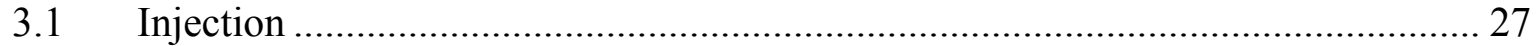

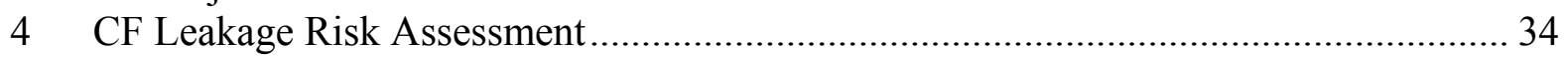

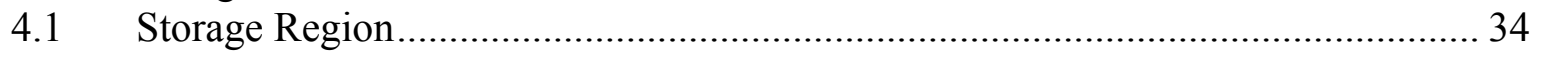

4.2 $\quad \mathrm{CO}_{2}$ and Brine Leakage Likelihood and Impacts .................................................... 37

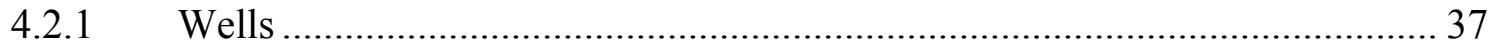

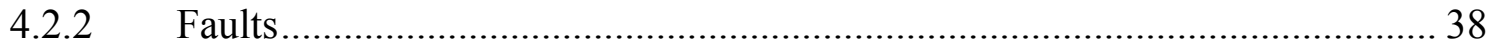

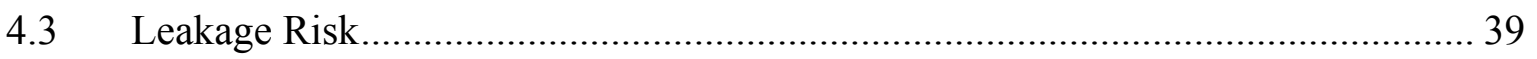

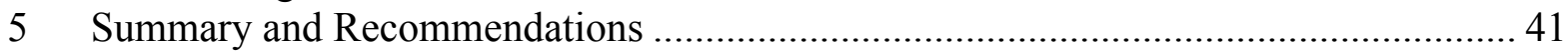

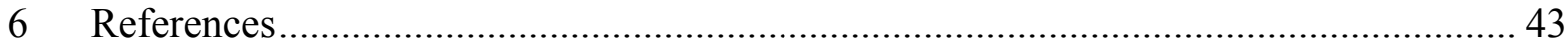

$7 \quad$ List of Acronyms ................................................................................................. 48

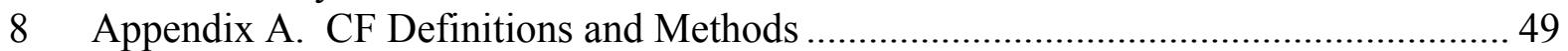

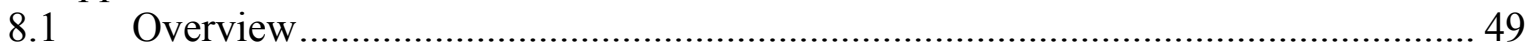

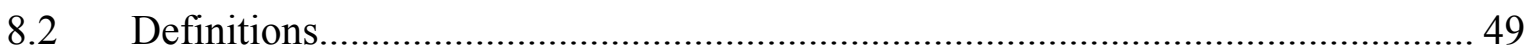

8.3 Compartments and Conduits....................................................................... 49

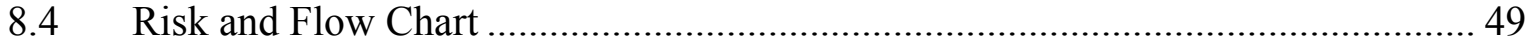


This page left intentionally blank. 


\section{List of Figures}

Figure 2.1. Site map of the greater Regina area showing the $20 \mathrm{~km}(12 \mathrm{mi})$ radius around the

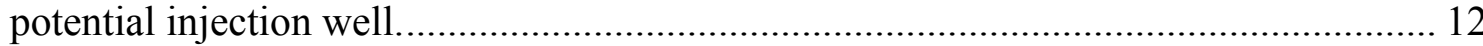

Figure 2.2. Wind Rose of the Regina area. Regina Airport. Golder Associates (2007)........ 13 Figure 3.1. (from Nicolas and Barchyn 2009) Map of Williston Basin and Surrounding Areas; shaded area is the Targeted Geoscience Initiative II Williston Basin Project Area

Figure 3.2. (from Khan and Rostron, 2004) Williston Basin Stratigraphic and Hydrostratigraphic Columns for the Area Near Weyburn............................................ 16

Figure 3.3. (from Bachu and Hitchon, 1996) Regional Groundwater Flow Pattern............... 17 Figure 3.4. (from Palombi and Rostron, 2006) Total Dissolved Solids in the CambroOrdovician Aquifer. The region in this figure corresponds to the gray shaded region in

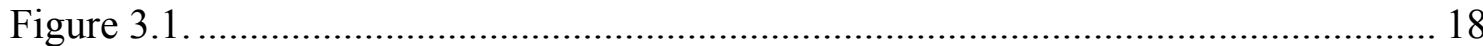

Figure 3.5. (from Nicolas and Barchyn 2009) Detailed deep Paleozoic stratigraphy: a)

Devonian period and b) Cambrian, Ordovician, and Sillurian periods......................... 22

Figure 3.6. Hydrostatigraphy and water quality (TDS) in the Regina area of the Williston Basin (salinity data from Palombi, 2008; stratigraphy from Palombi, 2008, Nicolas and Barchyn, 2009 and Williston Basin TGI:

http://www.gov.mb.ca/stem/mrd/geo/willistontgi/maps.html\#list).

Figure 3.7. (from Schlumberger, 2009 and Li and Morozov, 2007) Gravity and Magnetic

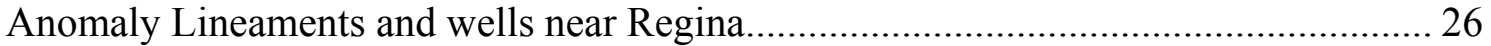

Figure 4.1. Gas saturation after 5 yrs of injection, constant pressure boundary condition.... 30 Figure 4.2. Gas saturation after 15 yrs of injection, constant pressure boundary condition.. 31 Figure 4.3. Gas saturation after 25 yrs of injection, constant pressure boundary condition.. 31

Figure 4.4. Gas saturation after 50 yrs (25 years of injection), constant pressure boundary

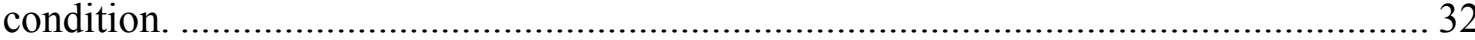

Figure 4.5. Pressure response at $20 \mathrm{~km}$ from injection well calculated using the Theis solution.

Figure 4.6. Maximum pressure rise as a function of distance from injection well calculated

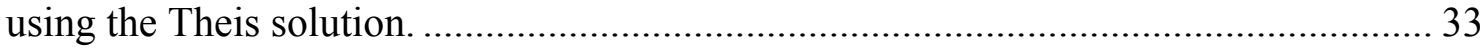

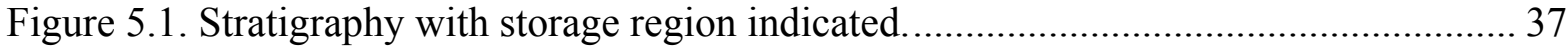

Figure A-1. Generic schematic of compartments and conduits in the CF........................... 50

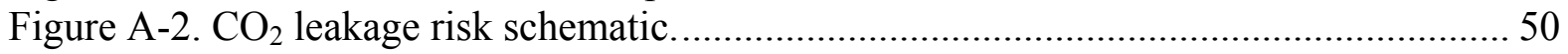

Figure A-3. Flow chart of CF process showing logic and inputs and outputs..................... 51

\section{List of Tables}

Table 4.1. Properties of the Deadwood storage formation and fluids ............................... 29

Table 4.2. Properties used in the reservoir simulation and catalog database query.............. 30

Table 4.3. Extent of $\mathrm{CO}_{2}$ plume for different boundary conditions compared with the

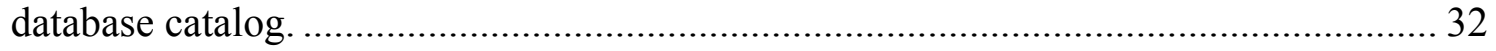

Table A.1. Tasks and Steps in the CF approach. ........................................................ 52 
This page left intentionally blank. 


\section{Executive Summary}

\section{Introduction}

A $\mathrm{CO}_{2}$ sequestration project is being considered to (1) capture $\mathrm{CO}_{2}$ emissions from the Consumers' Cooperative Refineries Limited at Regina, Saskatchewan and (2) geologically sequester the captured $\mathrm{CO}_{2}$ locally in a deep saline aquifer. This project is a collaboration of several industrial and governmental organizations, including the Petroleum Technology Research Centre (PTRC), Sustainable Development Technology Canada (SDTC), SaskEnvironment Go Green Fund, SaskPower, CCRL, Schlumberger Carbon Services, and Enbridge. The project objective is to sequester 600 tonnes $\mathrm{CO}_{2} /$ day. Injection is planned to start in 2012 or 2013 for a period of 25 years for a total storage of approximately 5.5 million tonnes $\mathrm{CO}_{2}$.

This report presents an assessment of the leakage risk of the proposed project using a methodology known as the Certification Framework (CF). The $\mathrm{CF}$ is used for evaluating $\mathrm{CO}_{2}$ leakage risk associated with geologic carbon sequestration (GCS), as well as brine leakage risk owing to displacement and pressurization of brine by the injected $\mathrm{CO}_{2}$. We follow the $\mathrm{CF}$ methodology by defining the entities (so-called Compartments) that could be impacted by $\mathrm{CO}_{2}$ leakage, the $\mathrm{CO}_{2}$ storage region, the potential for leakage along well and fault pathways, and the consequences of such leakage. An understanding of the likelihood and consequences of leakage forms the basis for understanding $\mathrm{CO}_{2}$ leakage risk, and forms the basis for recommendations of additional data collection and analysis to increase confidence in the risk assessment. .

\section{Potential Sequestration Site}

The location identified as a potential $\mathrm{CO}_{2}$ sequestration site is near the city of Regina, with a population of more than 200,000. Lying within the Canadian Great Plains, topographic relief is minimal. Land use in the general vicinity of the urban area is predominantly agricultural, with a variety of crops harvested. The site lies within the Williston Basin, a sedimentary basin found in southwestern Manitoba, southern Saskatchewan, the Dakotas and eastern Montana. The Williston basin is composed of sedimentary rocks overlying Precambrian crystalline rocks. This site lies near the northern edge of the basin, where the sedimentary rock is about 2,200 $\mathrm{m}(7,200 \mathrm{ft})$ thick, consisting mainly of sandstone, shale, carbonates, and evaporites. Geologic and hydrologic information for the basin are available from surveys concerned with petroleum and potash resources as well as other $\mathrm{CO}_{2}$ sequestration projects. However information specific to this location is relatively sparse. The target storage aquifer is the Cambro-Ordovician aquifer comprising the Winnipeg and Deadwood formations at the base of the sedimentary column. The aquifer lies at a depth of about 2,000 m (6,600 ft) and has a net sandstone thickness of about $111 \mathrm{~m}(360 \mathrm{ft})$. The aquifer has more than sufficient capacity to sequester 5.5 million tonnes of $\mathrm{CO}_{2}$ that are planned for injection over 25 years.

\section{Subsurface Hydrology and Storage Region}

Groundwater flow in the Williston Basin is governed primarily by basin-scale topography, variations in permeability, and fluid composition. Regional flow in the vicinity of the potential site is expected to be up-dip to the northeast. However, density effects caused by 
strong salinity gradients are expected to limit regional flow rates in the Cambro-Ordovician aquifer. The main stratigraphic sequence above the Cambro-Ordovician aquifer consists of Middle Ordovician-Mississippian carbonates and evaporites, including the economically significant potash deposits of the Prairie Evaporite. Above this lies the Bakken formation, a regional seal containing black shales. Above this lies the Pennsylvanian-Quaternary clastic units, consisting mainly of shale and sandstone that make up the remainder of the sequence, which notably includes an anhydrite/shale layer that also acts as a regional seal called the Watrous Aquitard.

Simulations conducted for this risk assessment indicate that the lateral region potentially affected by $\mathrm{CO}_{2}$ migration and brine displacement will be much less than $20 \mathrm{~km}$ (12 mi) from the injection site. Simulations of the $\mathrm{CO}_{2}$ plume indicate a plume size less than $1.8 \mathrm{~km}(1.1$ mi) in radius after 25 years of injection. Documented models and geochemical observations indicate that at a regional scale, flow and mixing occurs for ground waters from the CambroOrdovician aquifer up to the Bakken Formation. However, within the zone affected by $\mathrm{CO}_{2}$ injection, the presence of the Prairie Evaporite is expected to prevent upward migration of $\mathrm{CO}_{2}$ or brine through natural pathways, including faults. This leads to the definition of a storage region for the project that has a $20 \mathrm{~km}(12 \mathrm{mi})$ radius around the injection site with an upper boundary at the base of the Prairie Evaporite.

\section{Leakage through Wells}

Because the dip of the Winnipeg and Deadwood formations is uncertain but expected to be very small (less than $1^{\circ}$ ), it is not possible to predict with confidence the up-dip direction of buoyancy-driven flow. Therefore, nominally down-dip wells must be considered as potentially intersecting the buoyancy-driven $\mathrm{CO}_{2}$ plume. The nearest well to the potential injection location is the University of Regina geothermal well about $13 \mathrm{~km}$ (8 mi) down dip. There is also a well approximately $25 \mathrm{~km}(15 \mathrm{mi})$ nominally along strike to the southeast of the injection point. The nearest well nominally up-dip is about $40 \mathrm{~km}(25 \mathrm{mi})$ from the injection point. The intensity of deep-well development increases moving southeast toward known petroleum resources near Weyburn. All remaining wells are $40 \mathrm{~km}(25 \mathrm{mi})$ or more away from the injection point, with most of these being down dip. Because of the sparse well development, large distances between the proposed injection site and other wells, and the scarcity of wells along the nominal up-dip direction, the brine and $\mathrm{CO}_{2}$ leakage likelihood through wells is nearly zero. However, future development of re-injection wells associated with potash solution mining within the storage region footprint would result in increased potential for brine or $\mathrm{CO}_{2}$ leakage out of the storage region given that such wells represent a penetration that must be maintained and monitored to ensure wellbore integrity.

\section{Leakage through Faults}

Information on faults available from other investigations of the Williston Basin indicates that the flat-lying, unstructured rocks have a relatively low fault density. However, only indirect information concerning faults is available for this site. The existing information is based on lineaments interpreted from gravity and magnetic anomaly measurements. These lineaments suggest at least one potential fault immediately in the vicinity of the potential $\mathrm{CO}_{2}$ plume.

An important characteristic of faults relative to $\mathrm{CO}_{2}$ sequestration is their offset. Sealing formations that are thinner than the anticipated fault offset are not considered reliable to 
prevent upward migration of injected $\mathrm{CO}_{2}$ or displaced brine. Limited information from the Williston Basin indicates that major faults are subject to offsets on the order of $15 \mathrm{~m}(50 \mathrm{ft})$ or less in the Ordovician decreasing to below detection by the Upper Devonian. This leads to the interpretation that potential sealing formations between the Cambro-Ordovician aquifer and the Prairie Evaporite that are on the order of $15 \mathrm{~m}(50 \mathrm{ft})$ in thickness or less, such as the Icebox shale member of the Winnipeg Formation, may be subject to relatively substantial offset and cannot be relied upon to contain injected $\mathrm{CO}_{2}$ or displaced brine. The Prairie Evaporite is a low-permeability formation that has been found to act as a seal where present in the Williston Basin. This formation is present throughout the area and has a thickness of about $100 \mathrm{~m}(330 \mathrm{ft})$. Therefore, this formation is expected to prevent upward migration of injected $\mathrm{CO}_{2}$ or displaced brine through faults.

\section{Evaluation of Impacts}

The main potential impacts to consider are releases of $\mathrm{CO}_{2}$ and/or brine at the ground surface, incursion into potable water supplies, and $\mathrm{CO}_{2}$ entering potash resource areas. Potable water in the region lies well above the Prairie Evaporite and numerous additional geologic units that would perform as seals. Therefore, impacts associated with releases to potable water or to the surface via natural pathways are not likely. The potash resource, when present, is found in the Prairie Evaporite. However, potash zones are generally found near the top of the formation. $\mathrm{CO}_{2}$ is unlikely to migrate into the Prairie Evaporite owing to the number of potential seals deeper in the section as well as the character of the Evaporite. The Evaporite includes halite, which, like other evaporites, tends to have low permeability where pores are not enhanced by dissolution and also tends to flow such that any fractures and fault damage zones would be sealed. Consequently $\mathrm{CO}_{2}$ leakage to and impact upon potential potash resources in the Prairie Evaporite are considered unlikely.

Because of a lack of information concerning faults in the area and other uncertainties, there is a small potential for $\mathrm{CO}_{2}$ and brine to migrate to higher levels through faults. Fluids migrating above the Prairie encounter the Bakken and Watrous Aquitards which are considered regional seals. Above the Watrous Aquitard there are approximately $500 \mathrm{~m}(1,600$ $\mathrm{ft}$ ) of uninterrupted Cretaceous shales. All of these sealing formations underlie potable ground water resources. These barriers provide additional reassurance that injected $\mathrm{CO}_{2}$ and displaced brine will not reach the ground surface or impact potable water supplies. Brine leakage into the potash resource does not pose any impact because the ground water associated with the Prairie Evaporite has high levels of total dissolved salts. Therefore, the main, albeit low probability, impact is that some of the potash resource could be locally affected by $\mathrm{CO}_{2}$ leakage.

Combining the likelihood of leakage and associated impacts as determined by existing information, the $\mathrm{CO}_{2}$ and brine leakage risk for the potential project are estimated as nearly zero. Collection of additional data as recommended below will serve to reduce uncertainty, particularly regarding the presence of faults and their offsets.

\section{Recommendations}

The general area around the prospective injection site has excellent potential for $\mathrm{CO}_{2}$ sequestration in the deep, high-salinity brines of the Winnipeg/Deadwood aquifers at the base of the Williston Basin. Although there is a considerable amount of regional information concerning the Williston Basin from the standpoint of hydrogeology, mineral resources, and 
other $\mathrm{CO}_{2}$ sequestration activities, the lack of local, site-specific information to help characterize the site leads to uncertainty in assessing leakage risk and motivates more data collection. For example, it is possible that some of the regional behavior concerning interactions between aquifers may underestimate the local seal integrity.

The major data needs concern faulting and fault offset, seal integrity, and quantification of residual $\mathrm{CO}_{2}$ saturation. Furthermore, an assessment of future development of mineral resources is needed, in particular, with respect to potash solution mining and associated deep re-injection wells. Recommendations also include a high-resolution seismic imaging to check for faulting. Because some of the potential seals that could prevent $\mathrm{CO}_{2}$ upward migration are thin $(\sim 10 \mathrm{~m})$, it is important to resolve fault throws at this level. It is also recommended to take core samples from potential sealing layers to see if diagenetic alteration may have caused the seal to become brittle. Other recommendations include in-situ hydraulic testing to look for responses that may indicate leakage, laboratory relative permeability testing to investigate $\mathrm{CO}_{2}$ trapping, and detailed simulations of $\mathrm{CO}_{2}$ plume size, shape, and migration path, to check effects of stratigraphic dip, heterogeneity, regional flow, and fault effects. 


\section{Introduction}

The potential $\mathrm{CO}_{2}$ sequestration project evaluated here is an integrated carbon capture, transportation and storage project with the objective of demonstrating that geologic carbon sequestration (GCS) in a deep saline aquifer in the vicinity of Regina, Saskatchewan, is a safe, feasible solution for reducing $\mathrm{CO}_{2}$ emissions from industrial facilities in the area. The proposed $\mathrm{CO}_{2}$ source is the Consumers' Cooperative Refineries Limited (CCRL) refinery complex at Regina in southeastern Saskatchewan. The project under consideration consists of a collaboration of several industrial and governmental organizations, including the Petroleum Technology Research Centre (PTRC), Sustainable Development Technology Canada (SDTC), SaskEnvironment Go Green Fund, SaskPower, CCRL, Schlumberger Carbon Services, and Enbridge.

The $\mathrm{CO}_{2}$ injection rate evaluated is 600 tonnes/day $\left(3.3 \times 10^{5} \mathrm{~m}^{3} /\right.$ day at standard conditions of $15.5^{\circ} \mathrm{C}$, 1.013 bar) through a single wellbore starting in 2012 or 2013 for a 25 -year period. This equates to a total $\mathrm{CO}_{2}$ storage of about 5.5 million tonnes. The injection site has not been precisely located but will potentially be several kilometers north of the refinery complex. The $\mathrm{CO}_{2}$ injection is planned to target the Cambro-Ordovician brine-filled aquifer composed of the Winnipeg and Deadwood Formations that lie approximately $2 \mathrm{~km}$ (1.24 mi) below the land surface. The target formation is on the order of $160 \mathrm{~m}(520 \mathrm{ft})$ thick and consists of sandstone, conglomerate, and shale sequences. The aquifer brine is highly saline, with total dissolved solids in the range of 200,000 to $300,000 \mathrm{mg} / \mathrm{L}$, or about 6 to 9 times the total dissolved solids found in average seawater.

For the last few years, Lawrence Berkeley National Laboratory (LBNL), The University of Texas at Austin (UT), and the Texas Bureau of Economic Geology (TBEG) have been undertaking case studies to test and refine a risk assessment methodology for GCS called the Certification Framework (CF). The $\mathrm{CF}$ is used for evaluating $\mathrm{CO}_{2}$-and brine leakage risk. While risk assessment is a broad term that can address many different aspects of a project, the $\mathrm{CF}$ focuses on risk (which is a combination of event likelihood and consequences) of migration of $\mathrm{CO}_{2}$ and/or brine into groundwater resources, hydrocarbon and geothermal resources, or into the shallow subsurface and/or into the atmosphere. The CF methodology is summarized in Appendix A and described fully in Oldenburg et al. (2009).

The purpose of this report is to present a preliminary analysis of the $\mathrm{CO}_{2}$ leakage risk for the potential project using concepts and methods of the CF along with available data and assumptions. The scope includes subsurface processes that may lead to impacts both underground and in the near-surface environment, but specifically excludes risks associated with $\mathrm{CO}_{2}$ production at the refinery, its separation from flue gas, compression, transportation, and injection down the well. The risks considered in this assessment pertain exclusively to those associated with the injected $\mathrm{CO}_{2}$ after it enters the storage formation from the well screen. 


\section{Site Description}

\subsection{Surface and Climate}

In order to evaluate populations and surface resources that could be impacted by $\mathrm{CO}_{2}$ leakage if it were to occur, the CF methodology requires definition of the surface setting of the potential project. The CCRL plant is located northeast of Regina some hundreds of meters away from the Regina ring road $\left(50^{\circ} 29^{\prime} 15^{\prime \prime} \mathrm{N}\right.$, and $104^{\circ} 35^{\prime} 09^{\prime}$ ' $\left.\mathrm{W}\right)$ at an elevation of $586 \mathrm{~m}$ $(1,924 \mathrm{ft}$ amsl). Although a final decision on the injection site has not been made, for the purposes of this report the injection well is located approximately $4 \mathrm{~km}(2.5 \mathrm{mi})$ north of the CCRL (Schlumberger, 2009). A map of the area is shown in Figure 2.1.

Topographic relief in the area is minimal. The CCRL plant is located at a subtle topographic saddle. Within $20 \mathrm{~km}(12 \mathrm{mi})$ of the plant, elevation increases approximately $70 \mathrm{~m}(220 \mathrm{ft})$ to the east and approximately $25 \mathrm{~m}(80 \mathrm{ft})$ to the west decreasing approximately $70 \mathrm{~m}(220 \mathrm{ft})$ to the north and approximately $30 \mathrm{~m}(100 \mathrm{ft})$ to the south.

The city of Regina is south of the capture plant and well, with a population of more than 200,000 (2007) and a population density of about 1,500 people $/ \mathrm{km}^{2}$. Land use outside of the urban area is predominantly agricultural, with a variety of crops harvested. Approximately six heavily trafficked roads depart from Regina outward, connecting to surrounding towns.

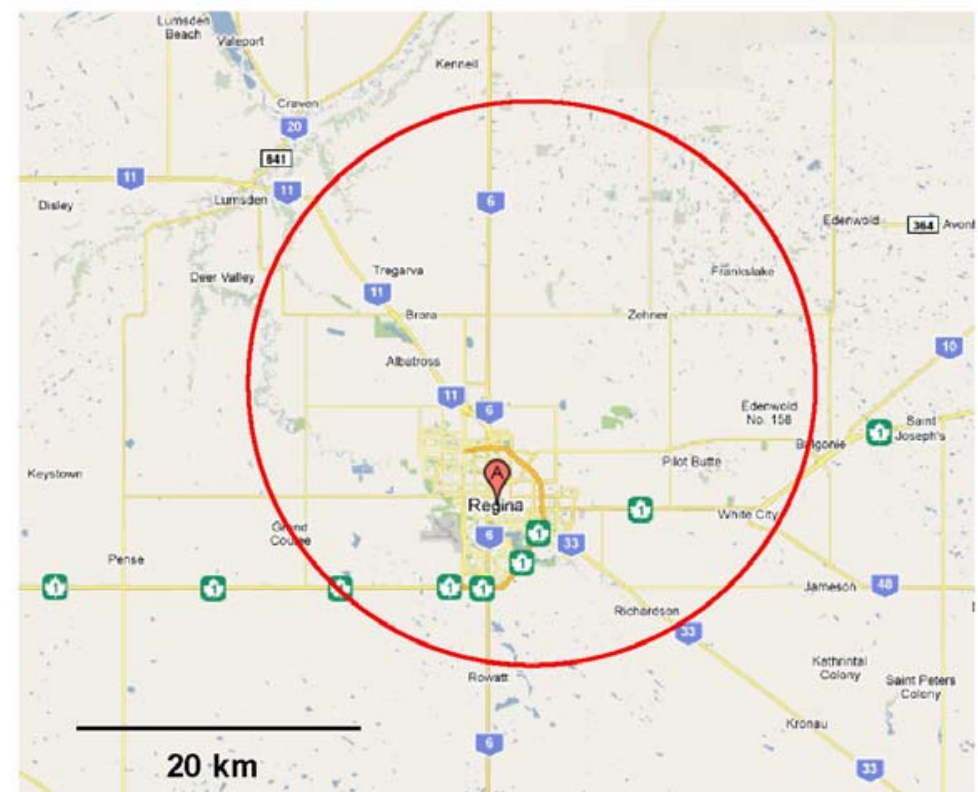

Figure 2.1. Site map of the greater Regina area showing the $20 \mathrm{~km}(12 \mathrm{mi})$ radius around the potential injection well.

Regina has a humid continental climate (Koppen climate classification Dfb) with strong semi-arid influences with warm summers and cold, dry winters, prone to extremes at all times of the year. The average daily temperature for the year is $2.9^{\circ} \mathrm{C}\left(37^{\circ} \mathrm{F}\right)$. Daily mean temperature ranges from $-16^{\circ} \mathrm{C}\left(23^{\circ} \mathrm{F}\right)$ in January to $19^{\circ} \mathrm{C}\left(66^{\circ} \mathrm{F}\right)$ in July. Average annual precipitation is $360 \mathrm{~mm}$ (14 in) and is heaviest from June through August (http://www.trailcanada.com/canada/weather/). Rainfall varies from $1 \mathrm{~mm}$ (0.04 in) in January to $67 \mathrm{~mm}$ (2.6 in) in June, while snowfall has a peak of $21 \mathrm{~cm}(8.2 \mathrm{in})$ in December. 
Average wind speed spans a fairly wide range, all year round, from lows of approximately 2 $\mathrm{m} / \mathrm{s}(4.4 \mathrm{mph})$ to highs of $8 \mathrm{~m} / \mathrm{s}(19 \mathrm{mph})$. Figure 2.2 shows the principal wind directions and speeds in the area.

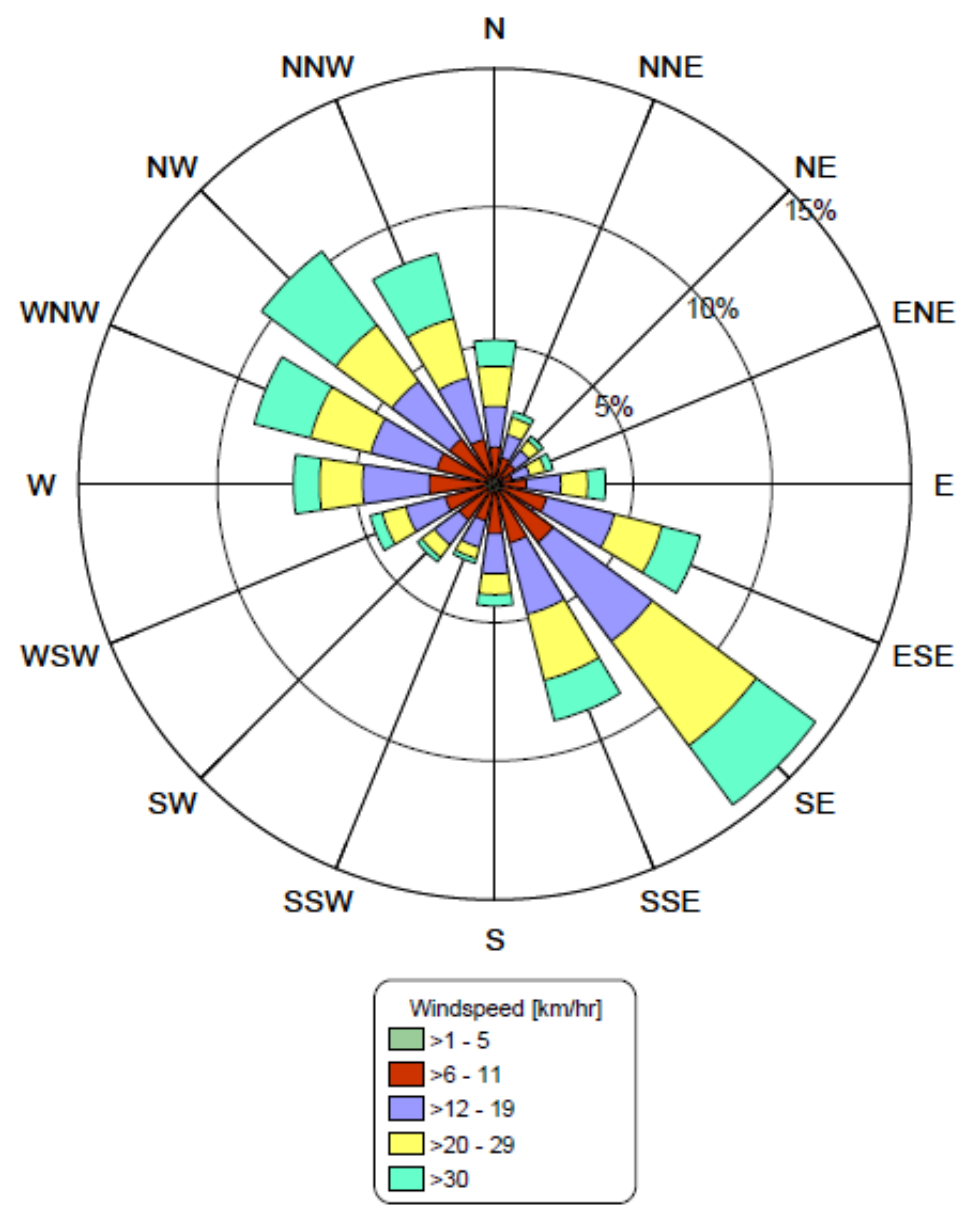

Figure 2.2. Wind Rose of the Regina area. Regina Airport. Golder Associates (2007)

\subsection{Surface Water}

The Qu'Appelle river flows some $30 \mathrm{~km}$ (19 mi) north of Regina and is the major river in this region. A dam created the Buffalo Pound reservoir, the major water reserve for the City that contributed in part to the early commercial development of the area. The Buffalo Pound reservoir has a holding capacity of about 92 million cubic meters (75,000 acre-ft) and a maximum depth of $5.5 \mathrm{~m}$ (18 ft) (Saskatchewna Water Authority, 2008).

Wascana Creek flows directly through Regina and is a tributary of the Qu'Appelle River. A reservoir associated with Wascana Creek, Wascana Lake in Regina, has a holding capacity of about 2.1 million cubic meters (1,700 acre-ft) (Saskatchewan Water Authority, http://www.swa.ca/WaterManagement/DamsAndReservoirs.asp\#). Wascana Marsh is a wetlands area in Regina along Wascana Creek. These surface water features lie about $8 \mathrm{~km}$ (5 mi) south of the refinery complex and more than $10 \mathrm{~km}(6 \mathrm{mi})$ from the tentative injection site. 
Other smaller artificial water reserves and natural lakes are present in the area. Depending on the $\mathrm{CO}_{2}$ leakage flux, $\mathrm{CO}_{2}$ leakage into surface water in Saskatchewan where there is large seasonal temperature variation would either dissolve into the water and then exsolve into the atmosphere as a result of water mixing processes, or $\mathrm{CO}_{2}$ could bubble directly to the surface and disperse into the atmosphere (Oldenburg and Lewicki, 2006).

\subsection{Subsurface}

\subsubsection{Introduction}

This section describes the geology, subsurface hydrology, significant subsurface resources, wells, and faults in the area as they pertain to leakage risk assessment in the CF methodology. Because CF leakage risk assessment addresses both likelihood and consequences of leakage, the properties of the subsurface system are critical to risk assessment because they control both the form and magnitude of leakage and subsurface resources that may be impacted by leakage.

\subsubsection{Geology}

The Williston Basin forms the southeastern extremity of the Western Canada Sedimentary Basin and is found in southwestern Manitoba, southern Saskatchewan, the Dakotas and eastern Montana as shown in Figure 3.1 (Kent and Christopher, 2008). The Williston basin is composed of Phanerozoic sedimentary rocks overlying Precambrian crystalline rocks composed mostly of meta-igneous and meta-sedimentary rocks (Burwash et al. 2008). The basin began to subside during the Cambrian Period, around 575 million years ago, and has undergone episodic subsidence throughout the rest of the Phanerozoic (Price, 2008). Basin subsidence and uplift along the flanking arches (see Figure 3.1) were main controls on sedimentation processes.

The general stratigraphic sequence (see Figure 3.2) begins with Cambrian-Middle Ordovician sandstones and shales that were deposited in a marine to shallow marine environment (Sorenson et al., 2009). The major formations are the Deadwood and Winnipeg. The Deadwood Formation consists of fine- to coarse-grained sandstones with some interbedded siltstones and shales. The Winnepeg Formation consists of a lower, poorly consolidated, quartz-rich sandstone unit and an upper shale unit (Nicolas and Barchyn, 2009). The overlying Middle Ordovician-Mississippian deposits consist of carbonates and evaporites, including dolostone, limestone, anhydrite, and economically significant potash deposits. The base of the Middle Ordovician-Mississippian deposits, the Red River Formation consisting mainly of carbonates and anhydrites, is overlain by shales and carbonates of the Stony Mountain Formation; both were deposited in marine to sabkha environments (Sorenson et al., 2009). Various dolostones and evaporites make up most of the overlying deposits from Silurian and Devonian periods. Notably, the Devonian Prairie Evaporite Formation consists of halite, anhydrite and economically significant deposits of potash.

The Bakken Formation, at the base of the Mississippian deposits, consists of two organic-rich black shale layers with an intervening sandstone-siltstone layer. The remainder of the Mississippian deposits consists mainly of carbonates and some evaporites (Nicolas and Barchyn 2009). The Mesozoic section consists mainly of shale and sandstone clastic units 
which make up the remainder of the sequence. Overall, sediment deposits in the Williston Basin exceed 4,500 m (14,800 ft) in thickness in some parts of the basin (Bachu and Hitchon, 1996).

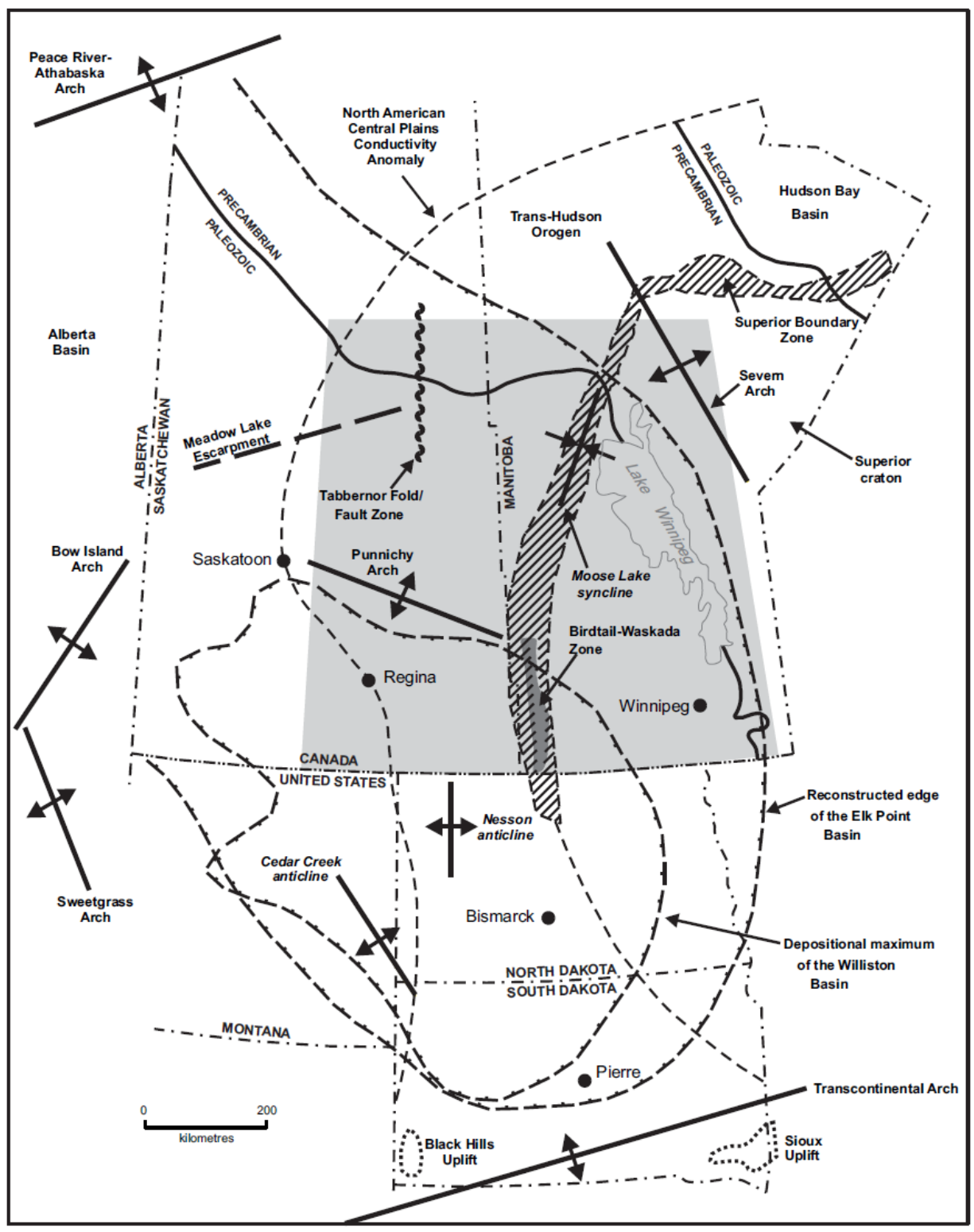

Figure 3.1. (from Nicolas and Barchyn 2009) Map of Williston Basin and Surrounding Areas; shaded area is the Targeted Geoscience Initiative II Williston Basin Project Area 


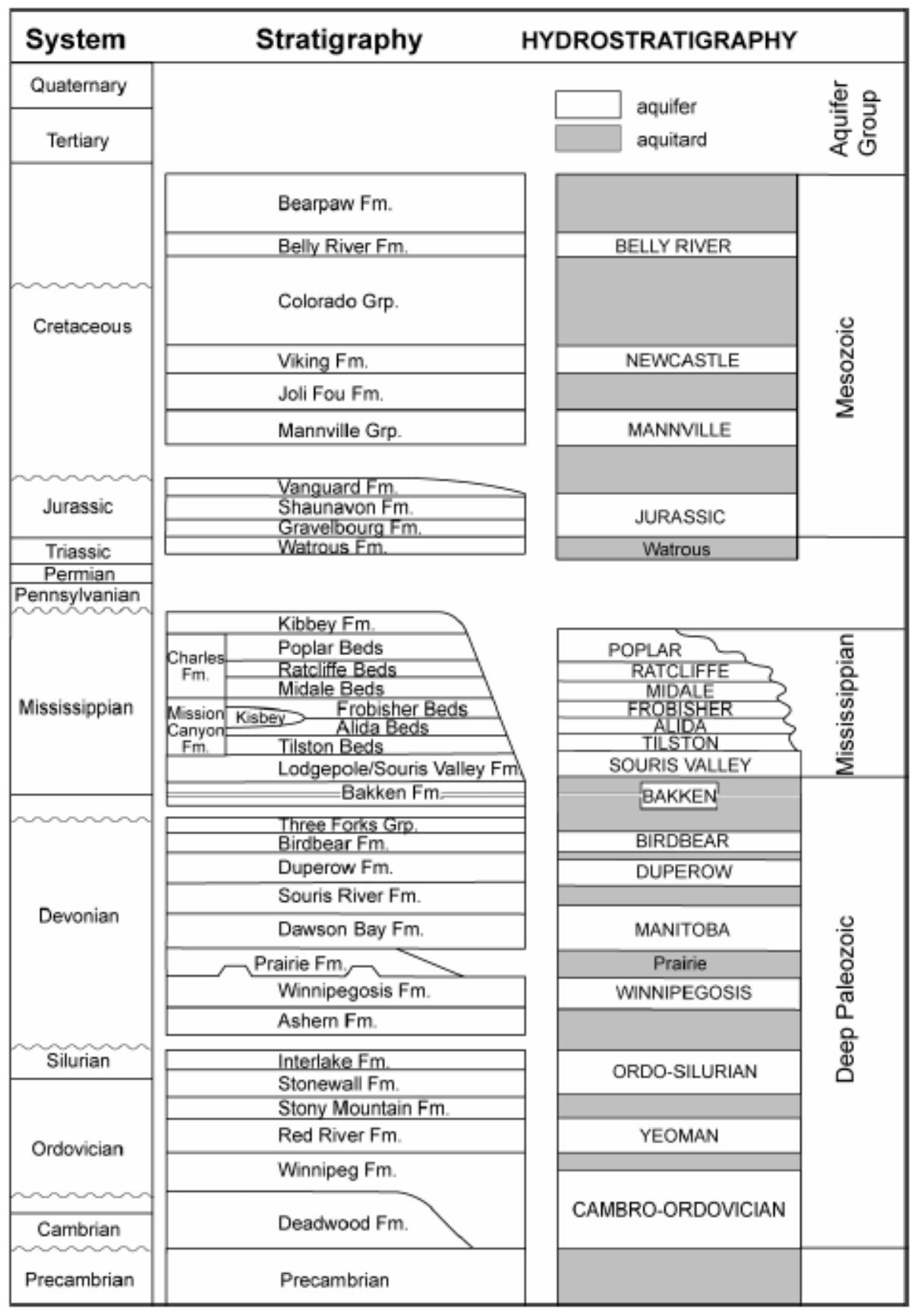

Figure 3.2. (from Khan and Rostron, 2004) Williston Basin Stratigraphic and Hydrostratigraphic Columns for the Area Near Weyburn.

\subsubsection{Subsurface Hydrology}

\section{Regional Subsurface Hydrology and Hydrogeochemistry}

Groundwater flow in the Williston Basin is governed primarily by basin-scale topography, variations in permeability, and fluid composition. The qualitative flow behavior is shown in Figure 3.3. Note that the hydrostratigraphy shown in Figure 3.3 differs from that shown in Figure 3.2. In several cases, but not all, the stratigraphy in Figure 3.3 rolls up the more 
detailed hydrostratigraphy shown in Figure 3.2 for a particular geologic time period in Figure 3.2 .

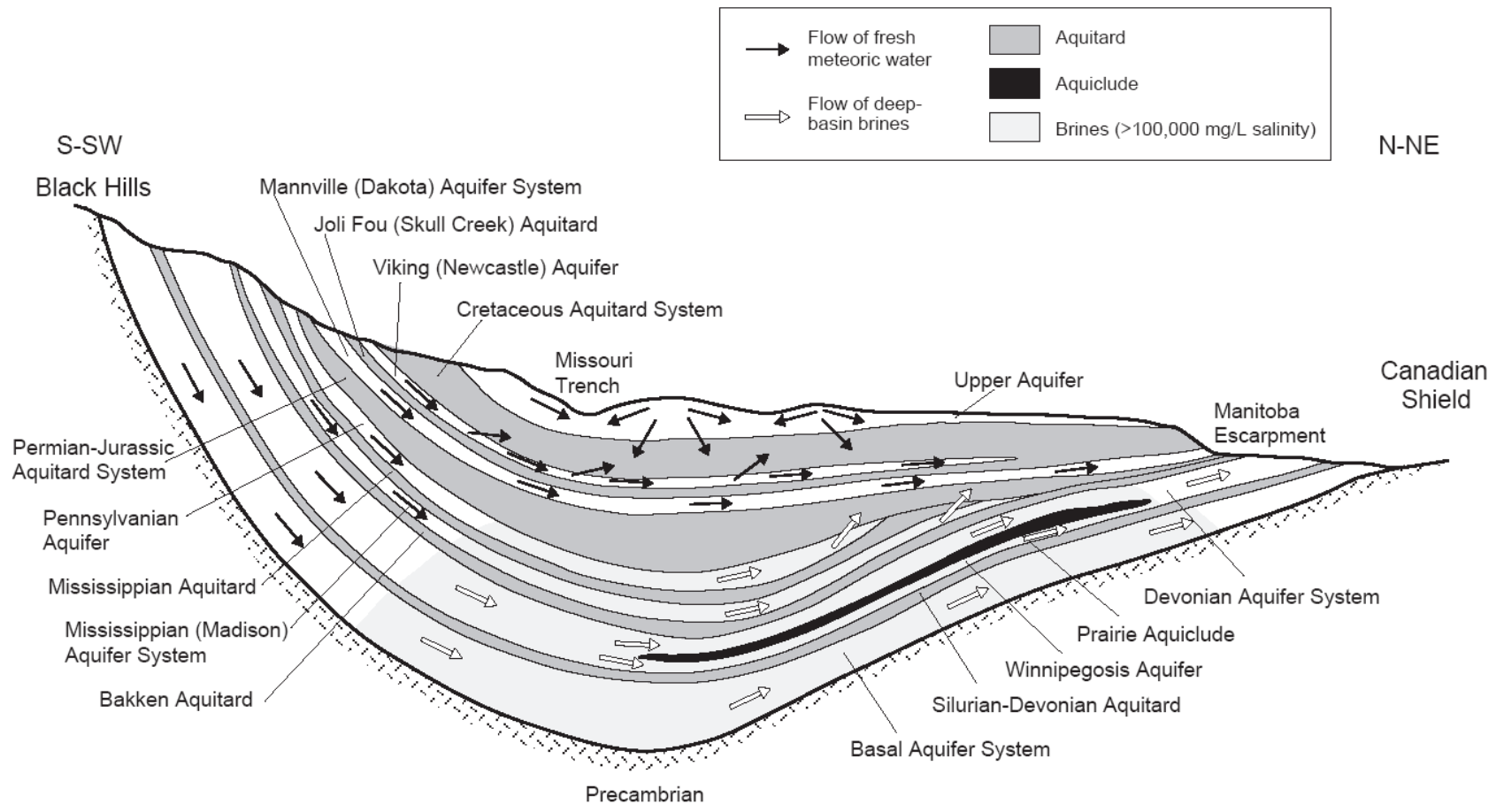

Figure 3.3. (from Bachu and Hitchon, 1996) Regional Groundwater Flow Pattern.

Because the Regina area is located near the northern portion of the basin, the regional flow based on Bachu and Hitchon (1996) is expected to be generally up-dip, i.e., towards the north-northeast. These flow directions are consistent with flow patterns shown in Palombi (2008) in the northeast portion of the Williston Basin. Hydrocarbon migration patterns have been found to be consistent with the dip and regional flow directions (Bachu and Hitchon, 1996). However, Khan et al. (2006) found that petroleum migration patterns were more consistent with a hydrostatic aquifer, which is the condition expected prior to the late Cretaceous to early Tertiary, with some later redistribution of petroleum accumulations by the present-day hydrodynamics. Penetration of lighter meteoric water in the deeper part of the basin tends to bypass the heavy brines and flow along the flanks of the basin (Bachu and Hitchon, 1996, p. 261), as suggested by simulation results (Downey and Dinwiddie, 1988). Brine density effects on flow in the lower Paleozoic aquifers were also found to be significant based on potentiometric analyses by Palombi (2008). Brunskill (2006) indicates that heavy brines $(\sim 300,000 \mathrm{ppm})$ in deeper portions of the Williston Basin may be stagnant. At the potential injection site, the brines are reported to be 200,000-300,000 ppm (Figure 3.4 and Schlumberger, 2009) and the injection interval is in the lowest portion of the basin. Therefore, the regional flow rate within the system may be relatively low.

Previous steady-state models of Paleozoic aquifers in the Williston Basin suggest that there is extensive leakage from the Cambrian through the Carboniferous aquifers (Mississippian as shown in Figure 3.2 for the Weyburn area) that is limited only higher up in the stratigraphic column by the Triassic and Jurassic beds (Bachu and Hitchon, 1996, p. 253). Observations of 
sulfate levels and saturation levels relative to anhydrite indicate that there is good hydrochemical continuity for all aquifers below the Prairie (potash) Formation (Bachu and Hitchon, 1996, p. 255). The similarity of flow patterns in the Basal and Winnipegosis aquifers indicates that the Silurian-Devonian aquitard is leaky; however, salinity data suggest that the Bakken aquitard is a strong barrier to fluid flow. Thus the geochemical data do not support the steady-state model results indicating leakage up to the Triassic and Jurassic beds (Bachu and Hitchon, 1996, p. 260). Note that the Bakken aquitard lies above the Prairie Formation that contains the potash resource.

Palombi (2008) found that the Winnipeg-Deadwood interval contains brine with 100 to 200 $\mathrm{g} / \mathrm{L}$ of total dissolved solids (TDS) in the Regina area. As shown in Figure 3.4, the TDS increases dramatically moving southwest toward the deeper portions of the CambroOrdovician aquifer. For the general region around Regina, the aquifers within the Lower Paleozoic Group contain waters with TDS ranging from $25 \mathrm{~g} / \mathrm{L}$ to over $200 \mathrm{~g} / \mathrm{L}$. Khan and Rostron. (2004, Figure 3) reports less than 10 to $50 \mathrm{~g} / \mathrm{L}$ TDS in the Mesozoic Mannville aquifer (Upper Clastic Unit) near Weyburn.

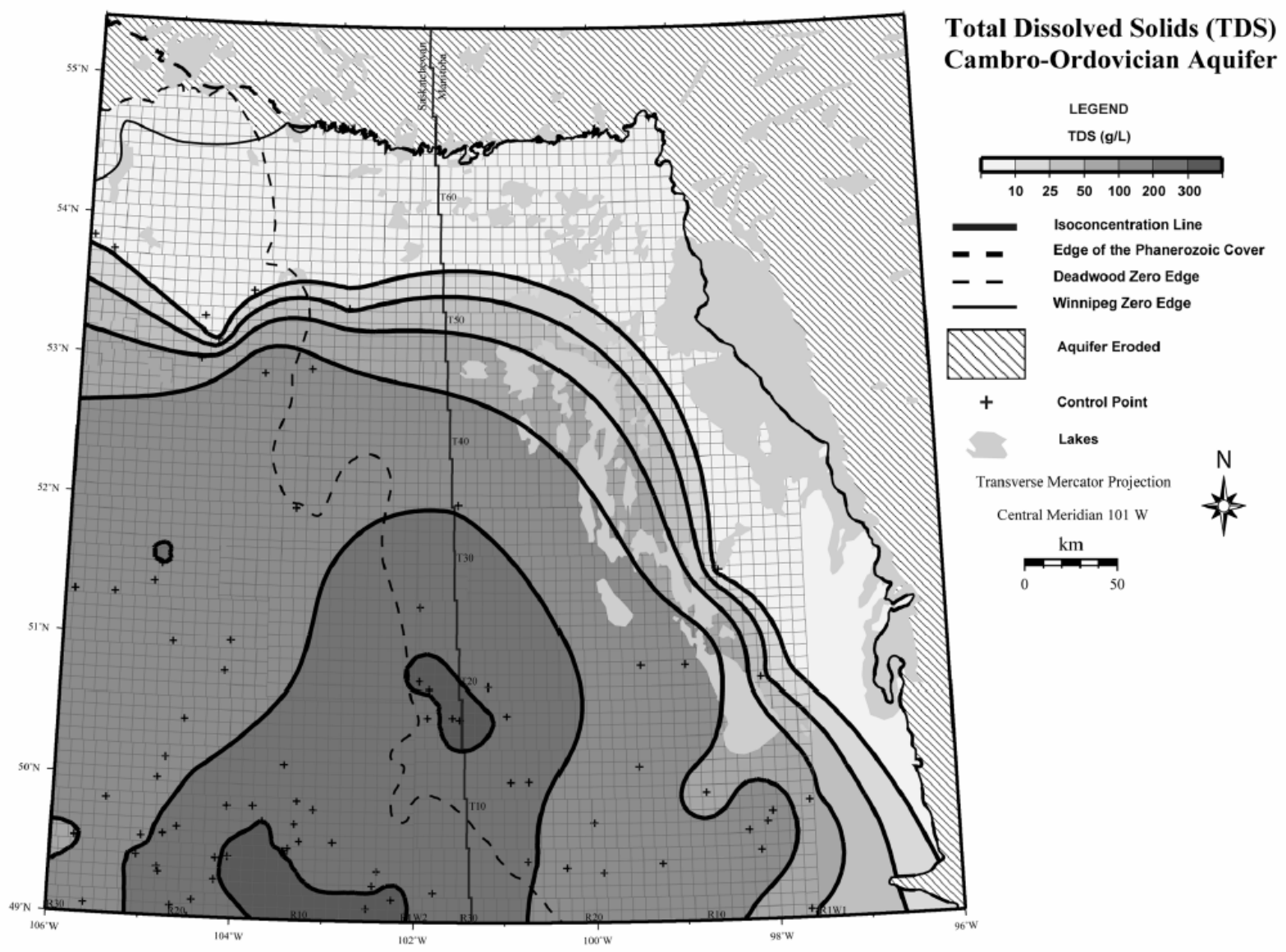

Figure 3.4. (from Palombi and Rostron, 2006) Total Dissolved Solids in the Cambro-Ordovician Aquifer. The region in this figure corresponds to the gray shaded region in Figure 3.1. 


\section{Local Hydrostratigraphy of the Cambro-Ordovician Section}

The Williston basin in the vicinity of Regina, Saskatchewan is composed of approximately 2,200 $\mathrm{m}(7,200 \mathrm{ft})$ of Phanerozoic sedimentary rocks overlying Precambrian crystalline rocks. The major strata consist of a Basal Clastic Unit (Cambrian-Ordovician) of sandstone and shale; a Carbonate-Evaporite Unit (Ordovician-Mississippian) of dolostone, limestone, salt, and anhydrite; and an Upper Clastic Unit (Jurassic-Cretaceous) composed predominantly of shale and sandstone (Vigrass et al., 2007). Detailed lithostratigraphy and the temperature profile are given by Vigrass et al. (2007, Figure 8). The temperature gradient appears to break to higher values within the Upper Clastic Unit.

The Deadwood is about $120 \mathrm{~m} \mathrm{(400} \mathrm{ft)} \mathrm{thick} \mathrm{and} \mathrm{consists} \mathrm{of} \mathrm{a} \mathrm{basal} \mathrm{conglomerate,}$ interbedded sandstone and shale, and thin beds of limestone and contains several permeable and confining units (Vigrass et al., 2007).

$\mathrm{CO}_{2}$ injection is planned for the Cambro-Ordovician brine aquifer composed of the Winnipeg and Deadwood Formations. The Black Island member of the Winnipeg Formation is a sandstone that is approximately $30 \mathrm{~m}(100 \mathrm{ft})$ thick; the overlying Icebox member of the Winnipeg Formation is a shale confining unit that is about $10 \mathrm{~m}(30 \mathrm{ft})$ thick. The Deadwood also consists of sand and shale layers, with a net sandstone thickness of about $80 \mathrm{~m}(260 \mathrm{ft})$. Vigrass et al. (2007) describes the Icebox member as a silty to sandy dolomitic mudstone in abrupt contact with the overlying sandy dolomitic limestone of the Yeoman Aquifer (Figure 3.2). The Winnipeg Formation in southeastern Manitoba was investigated by Underwood et al. (2009). In their description, the upper portion of this formation consists of a prominent shale layer (Icebox member of the Winnipeg Formation) of varying thickness containing cementing materials, iron oxides, iron sulfides, gypsum, and kaolinitic clay. Mineralogical XRD analyses of this material found that the dominant clay was kaolinite with minimal illite and traces of chlorite. Calcite, hematite and pyrite were also present.

\section{Hydrogeologic Properties of the Cambro-Ordovician Aquifer}

Vigrass et al. (2007) identifies porosities and permeabilities of the permeable sections of the Winnipeg and Deadwood Formations. These range from 11.2 percent to 17 percent porosity and 70 to 223 md permeability. The engineering report by Ruse (2004) indicates that injection of brines has been successfully carried out in the Winnipeg-Deadwood by several companies at sustained rates of 2300 to $7200 \mathrm{~L} / \mathrm{min}\left(80\right.$ to $\left.250 \mathrm{ft}^{3} / \mathrm{min}\right)$ or 3300 to 10,400 $\mathrm{m}^{3} /$ day. Bennion and Bachu (2005) report on relative permeability and capillary pressure measurements used by Schlumberger (2009) and in this report. The relative permeability measurements are for a $\mathrm{CO}_{2}$-displacing brine primary drainage process that also gives an estimate of irreducible water saturation, ranging from about 0.3 to 0.7 . A value of 0.5 was used for the simulations, with sensitivity analyses conducted for values of 0.3 and 0.7 . Capillary pressures are also measured for a primary drainage process. A value of 0.1 for residual gas was assumed in the Schlumberger (2009) simulations.

\section{Seals for the Cambro-Ordovician Aquifer}

The first potential seal for the Cambro-Ordovician aquifer is the Icebox member of the Winnepeg formation (Figure 3.5). The reported lack of clay-bound water (Schlumberger 2009 ) is an indication that the shale was exposed to high temperatures and pressures, and also is correlated with brittle conditions that may make the shale a poor seal. Ferguson et al. 
(2006) investigated the hydrology of the Winnipeg Formation in southeastern Manitoba. Their interpretation is that this shale layer serves as an effective hydraulic barrier separating the overlying Red River carbonates from the underlying Winnipeg Formation sandstones. This is also supported by hydrogen, oxygen, and strontium isotope variations between the Cambro-Ordovician and Yeoman aquifers (Rostron and Holmden, 2000). Vigrass et al. (2007, p. 9) reported that the Winnipeg aquifer was overpressured relative to the static gradient and that the basal Deadwood was underpressured, leading to a downward flow along the borehole between the two units. The pressure differences suggest that the Winnipeg and Deadwood are not in good hydraulic communication with each other suggesting that aquitards within the Deadwood may be an effective seal. Furthermore, the overpressure relative to the static gradient found in the Black Island member of the Winnipeg suggests that the Icebox shale directly above the Black Island sandstone is acting as a seal.

There are several aquifers and aquitards that lie between the Winnipeg Formation and the ground surface (Figure 3.2). The Washburn Study Area in the Williston Basin of North Dakota was investigated by Sorrenson et al. (2009) for $\mathrm{CO}_{2}$ sequestration. Sorrenson et al. (2009) identifies the Ordovician Stony Mountain Formation as the primary seal for the Red River Formation (the Yeoman in hydrostratigraphic nomenclature Palombi and Rostron (2006, Figure 2)). The Stony Mountain Formation is identified as a dolostone in the Vigrass et al. (2007, Figure 8) stratigraphy, but is described by Sorrenson et al. (2009) as a mixture of shales and low-permeability carbonates. The Stony Mountain Formation sits on top of an anhydrite layer called the Herald (Figure 3.5) in the Vigrass et al. (2007, Figure 8) stratigraphy, and has been identified as a seal (Nicolas and Barchyn 2009, p. 7). The Herald is about $12 \mathrm{~m}$ thick in the stratigraphy of Vigrass et al. (2007, Figure 8).

A relatively thin (10 m-thick) aquitard lies at the base of the Winnipegosis aquifer called the Ashern Formation. The Ashern formation is not identified by name on the Vigrass et al. (2007, Figure 8) stratigraphy, however, it appears to be indicated on the stratigraphic column as an unnamed layer. Nicolas and Barchyn $(2009$, p. 9) state that the Ashern Formation is a dolostone and shale that acts as a seal over the Interlake Group, which is identified as the Ordo-Silurian aquifer by Whittaker et al. (2009). This is the last aquitard above the Winnipeg/Deadwood aquifers before encountering the Prairie Evaporite containing the potash resource (Nicolas and Barchyn 2009, pp. 9-10).

As discussed above under regional hydrogeology, the Bakken Formation has been identified as a seal. This formation straddles the transition between Devonian and Mississippian deposits.

The Watrous aquitard (see Figure 3.2) separates the Upper Clastic Unit from the CarbonateEvaporite Unit at a depth of about $950 \mathrm{~m} \mathrm{(3,100} \mathrm{ft)} \mathrm{(Vigrass} \mathrm{et} \mathrm{al.} \mathrm{2007,} \mathrm{Figure} \mathrm{8).} \mathrm{Khan} \mathrm{and}$ Rostron (2004) identified this as a regional aquitard that separates aquifers containing lower and higher salinity waters. It consists of an anhydrite layer approximately $25 \mathrm{~m}(82 \mathrm{ft})$ thick underlain by a shale layer also about $25 \mathrm{~m}(82 \mathrm{ft}$ ) thick (Vigrass et al. 2007, Figure 8). Khan and Rostron (2004) states that the Watrous Aquitard is expected to be an excellent primary seal for $\mathrm{CO}_{2}$ injected into the Midale Aquifer in the Weyburn Field that lies about $120 \mathrm{~km}$ (75 mi) southeast of Regina. Small vertical pressure gradients and the absence of brines in the Upper Clastic Unit support the interpretation that there are no major vertically continuous heterogeneities in the Watrous Aquitard (Khan and Rostron 2004). 
(a)

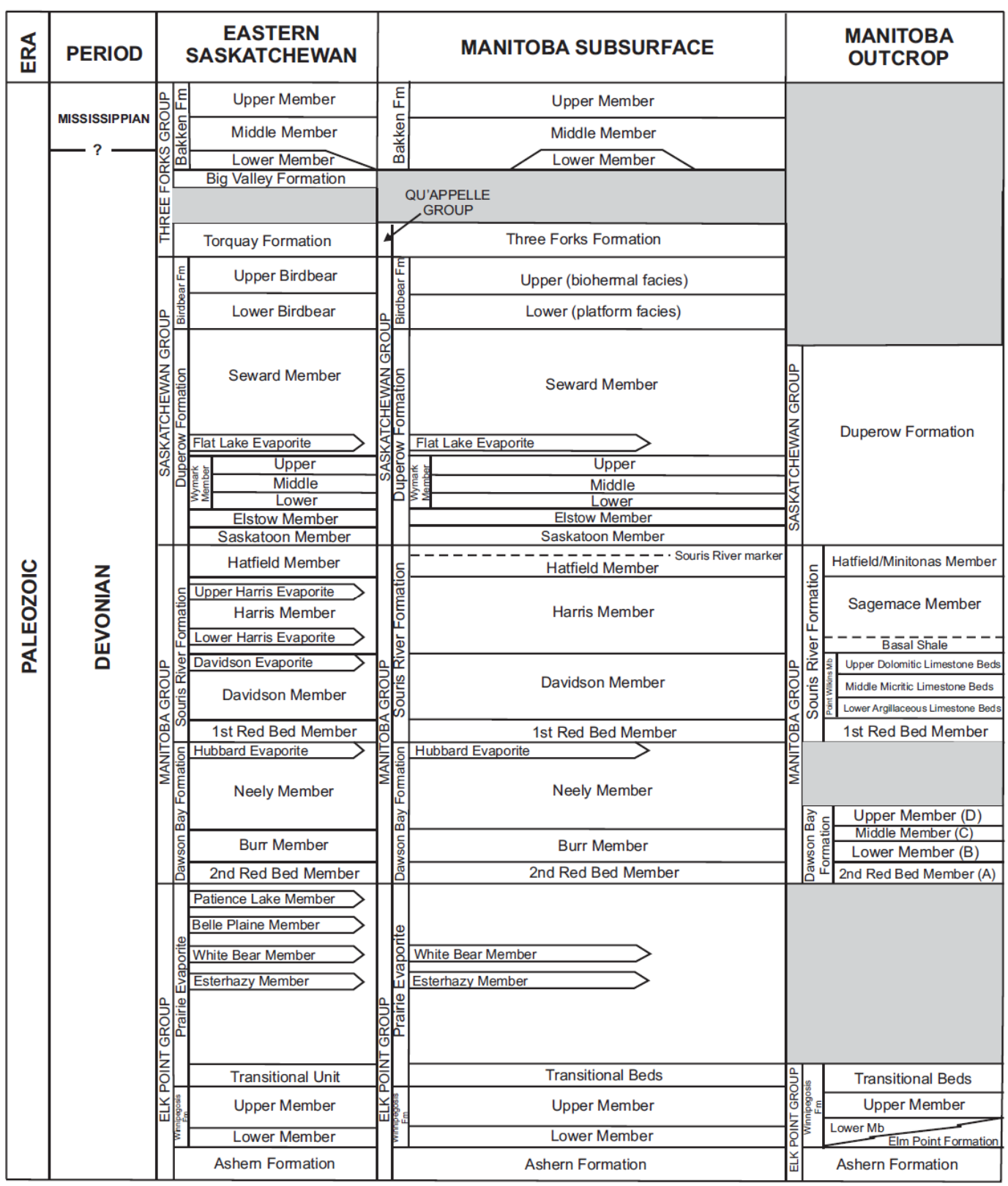


(b)

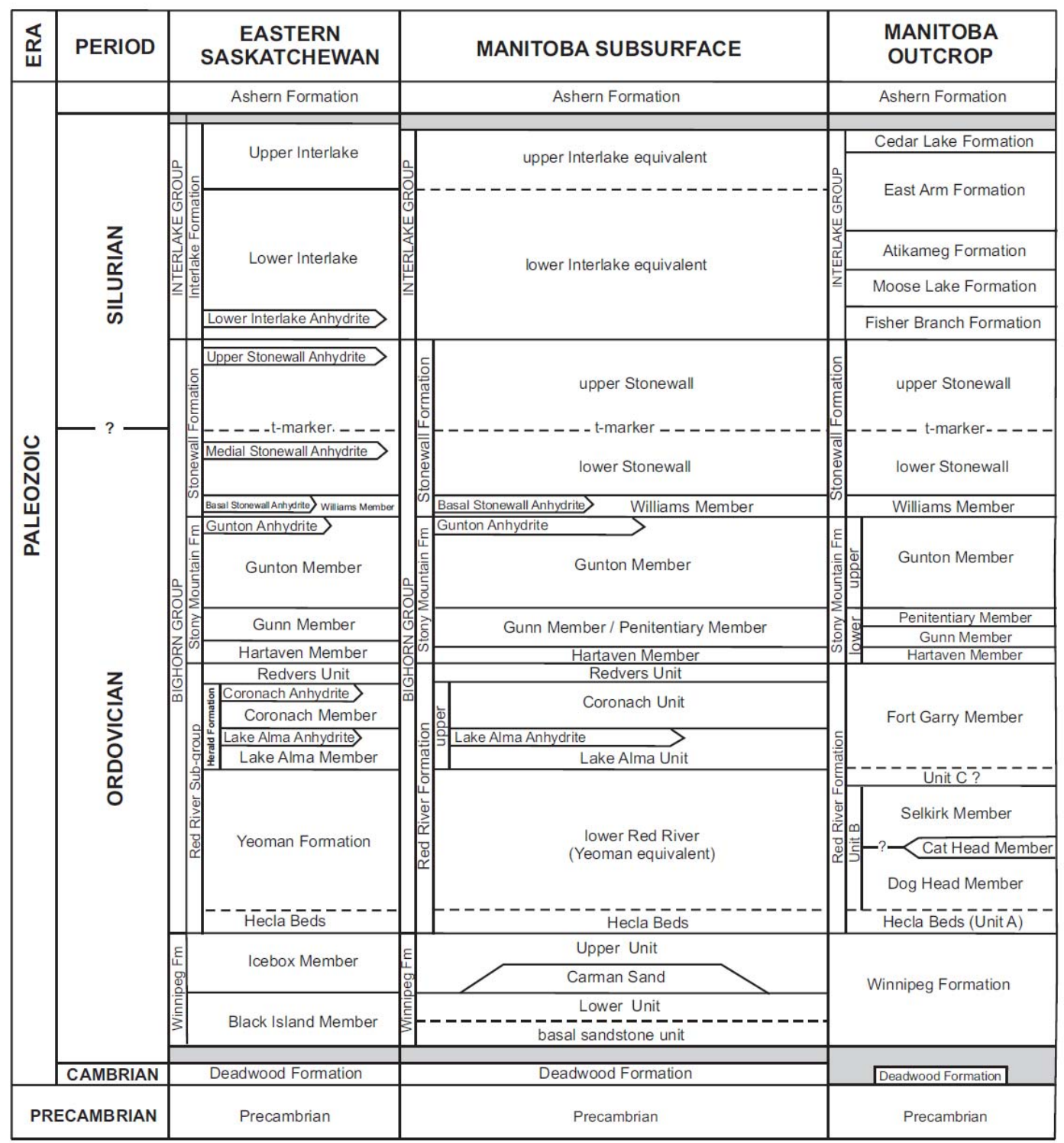

Figure 3.5. (from Nicolas and Barchyn 2009) Detailed deep Paleozoic stratigraphy: a) Devonian period and b) Cambrian, Ordovician, and Sillurian periods.

\subsubsection{Natural Resources}

The most significant subsurface natural resource in the Regina area is the Prairie Evaporite Formation potash deposit. This lies about $300 \mathrm{~m}$ above the Cambro-Ordovician aquifer targeted for $\mathrm{CO}_{2}$ injection. Other resources include low-grade geothermal energy used for space heating (Vigrass et al., 2007) and potable water. Petroleum resources have also been developed within the Williston Basin generally (e.g., Bunge 2001), although there are no known petroleum resources in the immediate vicinity of Regina. Potable groundwaters in the Regina area are found in the Judith River aquifer (also called the Belly River aquifer) (Pomeroy et al., 2005; Ridgley, 2002). The top of the aquifer lies about $200 \mathrm{~m}$ (660 ft) below ground surface (Figure 3.6) and is about $60 \mathrm{~m}(200 \mathrm{ft})$ thick. 


\section{Water Quality Goals Established in Saskatchewan}

The drinking water quality goals for Saskatchewan are given in Saskatchewan Environment (2006a). There are standards for some constituents, e.g., fluoride, mercury, and lead. Other water quality measures, such as total dissolved solids, are listed as objectives. Standards are legally enforceable requirements whereas compliance with objectives is not mandatory. A total dissolved solids value of $1,500 \mathrm{mg} / \mathrm{L}$ is listed as one of the objectives. Surface water quality goals are given in Saskatchewan Environment (2006b); the total dissolved solids objective for agricultural uses is a range from 500 to $3,500 \mathrm{mg} / \mathrm{L}$.

Figure 3.6 shows the pore-water total dissolved solids (TDS) profile relative to stratigraphic units and depth. The figure shows that TDS generally increases with depth; however some possible reversals are evident. The figure also shows that all deep groundwaters are saline relative to water quality objectives for drinking water and agricultural use. This is consistent with the other water quality studies in the region where the Mannville contained saline waters and was separated from shallower potable water sources by a 250 to $300-\mathrm{m}$ ( 820 to $980 \mathrm{ft}$ ) thick shale aquitard (Maathius and Simpson, 2006). 


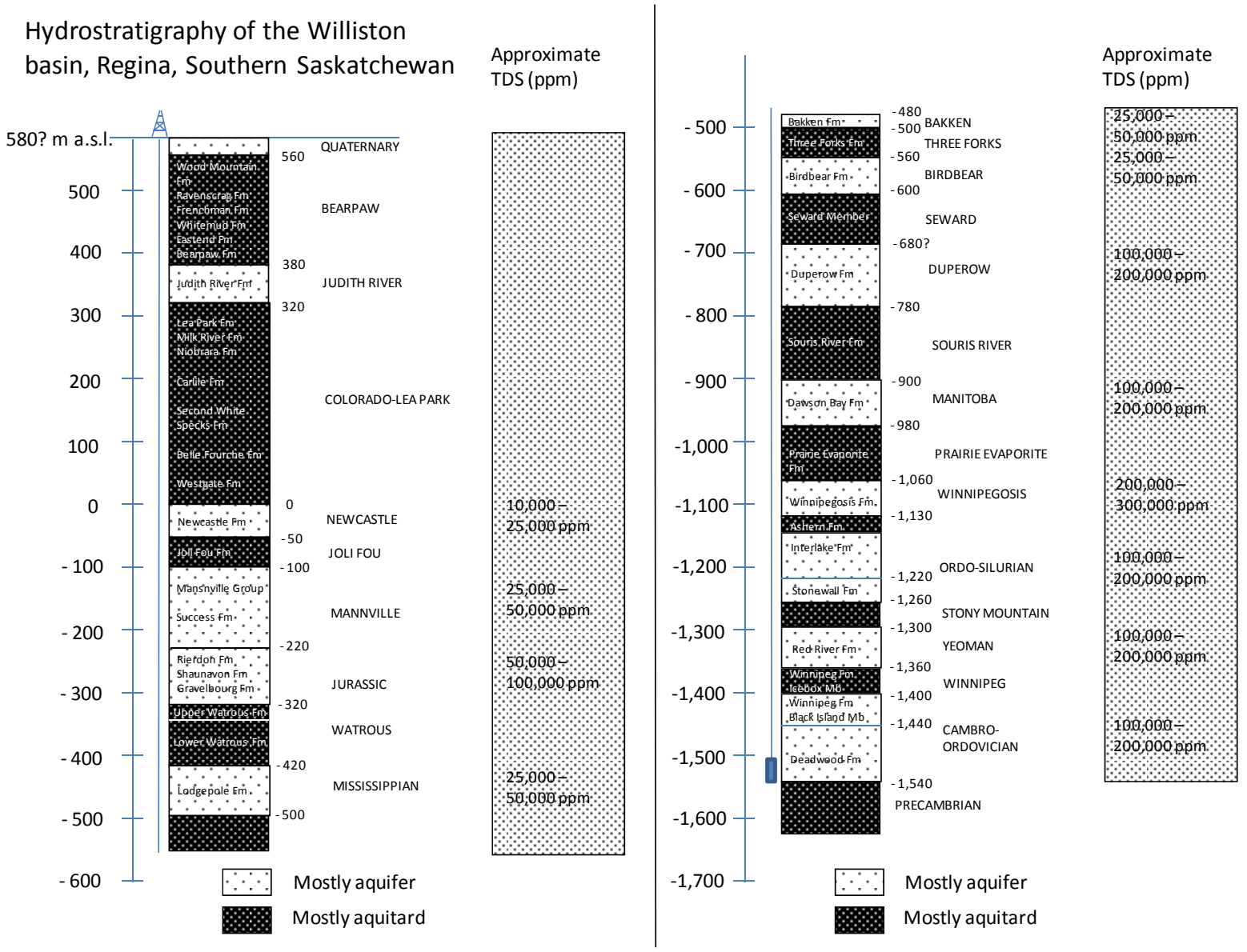

Figure 3.6. Hydrostatigraphy and water quality (TDS) in the Regina area of the Williston Basin (salinity data from Palombi, 2008; stratigraphy from Palombi, 2008, Nicolas and Barchyn, 2009 and Williston Basin TGI: http://www.gov.mb.ca/stem/mrd/geo/willistontgi/maps.html\#list).

Note: $1 \mathrm{mg} / \mathrm{L}=1000 / \rho \mathrm{ppm}$, where $\rho$ is the brine density in $\mathrm{kg} / \mathrm{m}^{3}$. For the Winnipeg/Deadwood formation brine having a density of $1180 \mathrm{~kg} / \mathrm{m}^{3}, 1 \mathrm{mg} / \mathrm{L} \approx 0.85 \mathrm{ppm}$.

\subsubsection{Faults and Fractures}

In the absence of leaking wells, the main potential leakage pathways considered in the CF are faults and fractures. Site-specific information on faults in the Regina area is very limited. As part of an investigation of petroleum resources of the Williston Basin, Price (1994) indicates that the Williston Basin has only flat-lying, unstructured rocks with almost no significant faulting. Sipple et al. (1995) investigated faulting in the Red River area of the Williston basin along the North Dakota - South Dakota border. Larger faults were found to have about $15 \mathrm{~m}$ $(50 \mathrm{ft})$ of throw at the Ordovician Winnipeg; fault throw was found to decrease moving upward through the stratigraphic sequence and is generally not detectable by the Upper Devonian time. This suggests that although the 10-m thick Icebox shale may be subject to complete offset by faults, the thicker Stony Mountain Formation is not expected to be completely offset by faulting (see also Section 3.3.3). 
Bunge (2001) investigated fracturing and faulting in the Weyburn field and characterized fractures within the Mississippian Group using oriented core and electrical micro imaging (EMI) logs. He found three fracture sets at strikes of $40^{\circ}, 285^{\circ}$, and $328^{\circ}$ and fracture densities ranging from 1 to 3.8 per meter. Information from gamma ray logs from several horizontal wells evaluated by Bunge (2001) indicate small-scale faults with less than $5 \mathrm{~m}$ of throw and a density of about 1.7 faults $/ \mathrm{km}$ in the NE-SW and NW-SE directions. Seismic data (3D and 2D) were used to identify fracture mechanisms; however, the small-scale faults could not be detected from the available seismic data.

The use of lineaments to evaluate faults is reported by Gorecki et al. (2009) for a $\mathrm{CO}_{2}$ sequestration evaluation of the Dickinson study area in the Williston Basin (North Dakota) and Lyatsky et al. (2003) discuss the use of gravity and magnetic surveys to map basement faults. Penner (2006) investigated the relationship between lineaments and faults in the Weyburn region of southeastern Saskatchewan. Approximately half of the lineaments identified were found to lie within $500 \mathrm{~m}$ of a fault. Li and Morozov (2007, map 25) shows gravity and magnetic lineaments in the region studied for the Williston Basin Targeted Geoscience Initiative (TGI) II. These represent potential basement faults or other significant structures within the Williston Basin. A northwest-southeast trending lineament is about two kilometers northeast of the potential injection site (Figure 3.7); note that the plume migration direction is potentially to the northeast as might be expected based on stratigraphic dip, regional flow patterns, and hydrocarbon migration patterns discussed in Section 3.3.3, as well as simulation results presented by Schlumberger (2009). Nevertheless, because of the relatively small dip and regional flow, the plume direction, especially the initial period during and immediately following injection, is considered uncertain. Other factors that are presently unknown, such as permeability anisotropy or high-permeability channels may cause alternative plume behavior. 


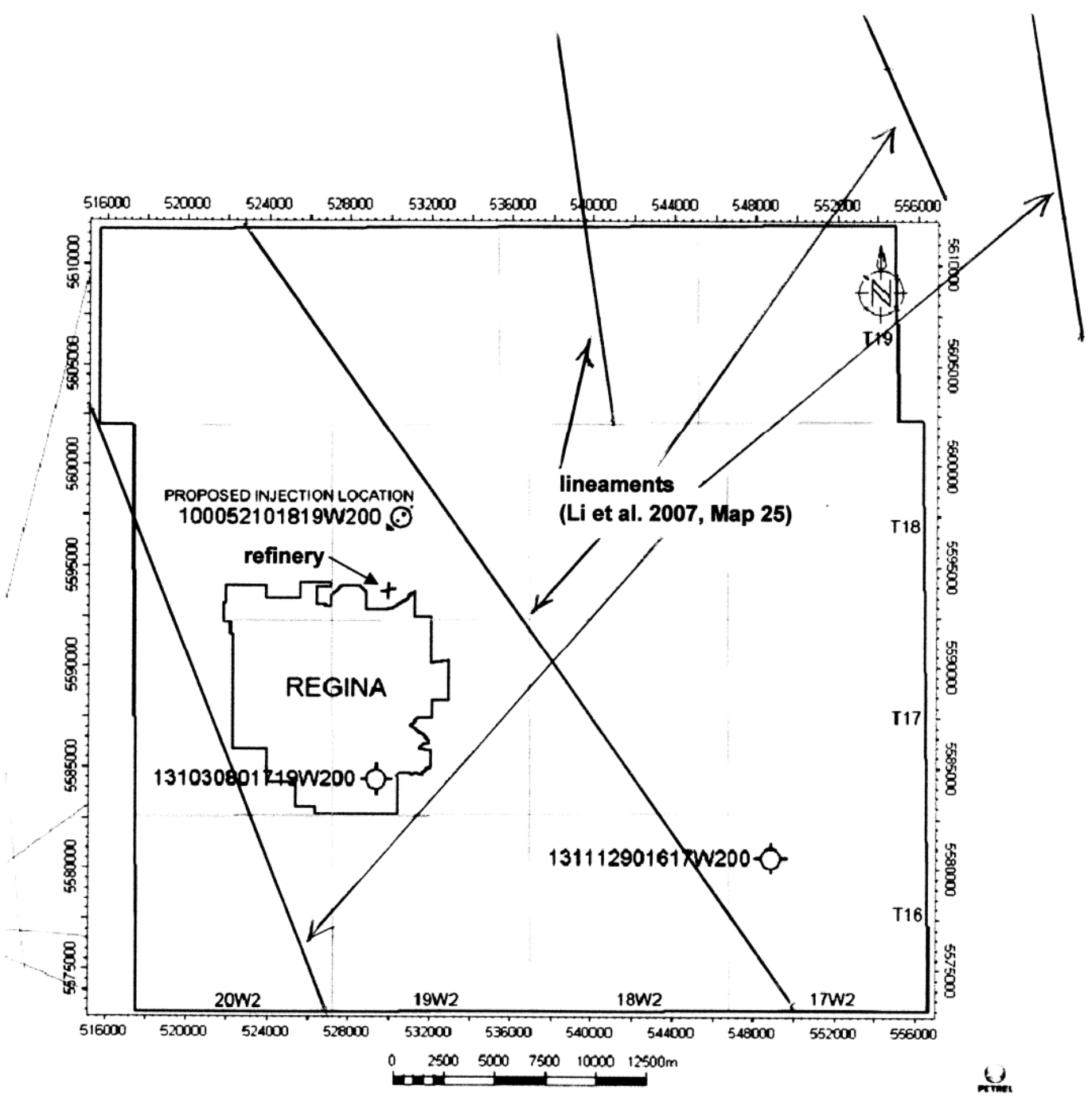

Figure 3.7. (from Schlumberger, 2009 and $\mathrm{Li}$ and Morozov, 2007) Gravity and Magnetic Anomaly Lineaments and wells near Regina. 


\section{Reservoir Modeling}

\subsection{Injection}

In order to estimate the locations of potential leakage of $\mathrm{CO}_{2}$ and brine and the associated driving forces as used in the $\mathrm{CF}$ approach, we use two modeling-based approaches: (1) direct numerical reservoir simulation of $\mathrm{CO}_{2}$ injection using the CMG (Computer Modelling Group) GEM code; and (2) estimation of the $\mathrm{CO}_{2}$ plume size by referring to the CF catalog of pre-computed results (e.g., Oldenburg et al., 2009). The properties of the Deadwood storage formation are presented in Table 4.1. The catalog was generated in 2008-2009 using discrete values of various properties that do not exactly match the estimated properties. The closest values to the these properties used in the catalog are given in Table 4.2 along with the values used in the GEM simulation. Several of the parameters for the simulation and database catalog cases are quite different. However, the simulation and database catalog information were used primarily to investigate the $\mathrm{CO}_{2}$ plume dimensions. The plume dimensions are principally affected by the average displacement rate, $q$, at a given radius, $r$, from the well,

$$
q=\frac{Q}{2 \pi r H \phi\left(1-S_{w i}\right)}
$$

where $Q$ is the well injection rate, $H$ is the aquifer thickness, $S_{w i}$ is the irreducible water saturation, and $\phi$ is the porosity. Using the parameters for the simulation and database cases, we find that

$$
\frac{q_{S}}{q_{D}}=\frac{Q_{S} H_{D} \phi_{D}\left(1-S_{\text {wiD }}\right)}{Q_{D} H_{S} \phi_{S}\left(1-S_{\text {wis }}\right)}=1.05
$$

where the subscripts $S$ and $D$ refer to the simulation and database cases. Parameters are from Table 4.2, except for residual water saturation. Note the the simulation case used a residual water saturation of 0.5 while the database case used a value of 0.55 . A $5 \%$ discrepancy between the nominal displacement rates for the simulation and database cases is not significant for the purposes of this evaluation given the level of other uncertainties.

Model properties are as shown in Table 4.1. The 50-m thickness corresponds to the Winnipeg and Basal Deadwood units, which have the lowest shale content and were shown by drillstem tests to be permeable. Also, the model was not set-up to explicitly account for the smaller-scale shale layers. The restriction to injection into these intervals is consistent with limited communication that may result from higher shale content in the other Deadwood units. A radial grid with 24,000 cells was used for the simulations. The radial grid dimensions coarsened outward logarithmically from $0.3 \mathrm{~m}(1 \mathrm{ft})$ to $4 \mathrm{~km}(13,000 \mathrm{ft})$ using 50

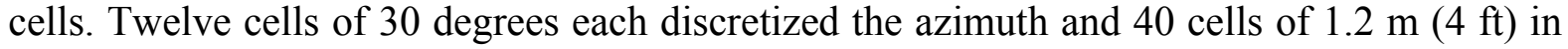
thickness were used in the vertical direction. 
Two simulations were conducted to investigate the influence of the outer boundary condition. For one case, the boundary condition is constant (hydrostatic) pressure at a distance of approximately $22 \mathrm{~km}$ (14 mi) from the injection well. For the second case, a closed-boundary (no flux) condition is used at the same distance. The initial condition is hydrostatic pressure everywhere. The injection rate at standard conditions $\left(15.5^{\circ} \mathrm{C}, 1.013 \mathrm{bar}\right)$ is assumed to be $3.21 \times 10^{5} \mathrm{~m}^{3} /$ day $\left(1.1 \times 10^{7} \mathrm{ft}^{3} /\right.$ day $)$ for 25 years for a total of $2.93 \times 10^{9} \mathrm{~m}^{3}\left(10^{11} \mathrm{ft}^{3}\right)$ or 5.48 $\times 10^{6}$ tonnes. At reservoir conditions, the volumetric injection rate is $793 \mathrm{~m}^{3} /$ day $\left(2.8 \times 10^{4}\right.$ $\mathrm{ft}^{3} /$ day) for a total of $7.23 \times 10^{6} \mathrm{~m}^{3}\left(2.6 \times 10^{8} \mathrm{ft}^{3}\right)$ The simulation included the evolution of the system for 500 years after cessation of injection.

Simulation results for the $\mathrm{CO}_{2}$ plume are shown in Figure $4.1-4.4$ using the constantpressure boundary condition. The plume is seen to expand nearly symmetrically for the first 50 years to a distance just over $2 \mathrm{~km}(6,600 \mathrm{ft})$. As discussed in Sec. 3.3.5, the dip at the site is sufficiently small that the plume cannot be counted on to move to the northeast (up dip) by buoyancy force, but rather could move in any direction as controlled by the local dip and permeability fields. Thus the roughly circular plume shape shown here should be used only as a guide to indicate approximate size of the plume. Note that the stratigraphic dip used in the simulation $\left(0.41^{\circ}\right.$, Table 4.2$)$ was slightly larger than the best-estimate of dip $\left(0.3^{\circ}\right.$, Table 4.1). The effect of this minor discrepancy on the solution is conservative in terms of potential buoyancy-driven spreading of the plume up-dip.

The size of the $\mathrm{CO}_{2}$ plume is summarized in Table 4.3 for both the simulations (using both constant $P$ and closed boundary conditions) and the catalog look-up. The extent of the $\mathrm{CO}_{2}$ plume is predicted by both the simulation and catalog look up to be approximately 1,500 $\mathrm{m}$ $(5,000 \mathrm{ft})$ after 25 years of injection. As shown in Table 4.3, the catalog look-up (database) values for $\mathrm{CO}_{2}$ plume size are good approximations to the simulation results. Furthermore, simulation results of $\mathrm{CO}_{2}$ plume size show weak dependence on boundary condition. In summary, the circular $\mathrm{CO}_{2}$ plume produced by the potential injection is expected to be less than $1.8 \mathrm{~km}(6,000 \mathrm{ft})$ in radius after 25 years. These results compare favorably with the earlier simulations by Schlumberger (2009).

Because of the influence of the simulation boundary conditions at large distances from the well, the pressure behavior at $20 \mathrm{~km}$ (12 mi) was computed using the Theis analytical model. The pressure response is shown in Figure 4.5. This indicates that maximum pressure perturbation at a distance of $20 \mathrm{~km}(12 \mathrm{mi})$ from the injection well is on the order of $1 \mathrm{bar}$. Figure 4.6 shows the maximum pressure rise as a function of distance from the injection well. The maximum pressure at $6 \mathrm{~km}(4 \mathrm{mi})$ is about 2 bars and drops to about 0.5 bars at 40 $\mathrm{km}(25 \mathrm{mi})$. The parameters used for the Theis pressure calculation are given in Table 4.1. 
Table 4.1. Properties of the Deadwood storage formation and fluids

\begin{tabular}{|c|c|c|c|c|c|}
\hline $\begin{array}{l}\text { Quantity } \\
\text { Description }\end{array}$ & Symbol & Value & Units & Value & Units \\
\hline formation pressure & $P$ & $2.23 \mathrm{E}+07$ & $\mathrm{~Pa}$ & 223 & bars \\
\hline $\begin{array}{l}\text { formation } \\
\text { temperature }\end{array}$ & $T$ & 59 & ${ }^{\circ} \mathrm{C}$ & 138.2 & ${ }^{\circ} \mathrm{F}$ \\
\hline dip of sealing unit & $\alpha$ & 0.00524 & radians & 0.3 & degrees \\
\hline formation thickness & $B$ & 50 & $\mathrm{~m}$ & & \\
\hline permeability & $k$ & $3.40 \mathrm{E}-13$ & $\mathrm{~m}^{2}$ & 345 & md \\
\hline porosity & $\phi$ & 0.152 & & & \\
\hline specific storativity & $S_{S}$ & $1.57 \mathrm{E}-06$ & $\mathrm{~m}^{-1}$ & & \\
\hline $\begin{array}{l}\text { formation water } \\
\text { salinity }\end{array}$ & $S$ & $2.50 \mathrm{E}+05$ & ppm & $25 \%$ & \\
\hline $\begin{array}{l}\text { water (brine) } \\
\text { density }\end{array}$ & $\rho_{\mathrm{W}}$ & 1180 & $\mathrm{~kg} / \mathrm{m}^{3}$ & & \\
\hline $\begin{array}{l}\text { water (brine) } \\
\text { viscosity }\end{array}$ & $\mu_{\mathrm{w}}$ & $1.01 \mathrm{E}-03$ & $\mathrm{~Pa}-\mathrm{S}$ & $1.01 \mathrm{E}+00$ & $\mathrm{cp}$ \\
\hline $\mathrm{CO}_{2}$ injection rate & $Q_{c}$ & $9.18 \mathrm{E}-03$ & $\mathrm{~m}^{3} / \mathrm{s}$ & $7.93 \mathrm{E}+02$ & $\mathrm{~m}^{3} /$ day \\
\hline $\begin{array}{l}\mathrm{CO}_{2} \text { injected } \\
\text { volume }\end{array}$ & $V_{0}$ & $7.23 \mathrm{E}+06$ & $\mathrm{~m}^{3}$ & & \\
\hline $\begin{array}{l}\mathrm{CO}_{2} \text { injected } \\
\text { density }\end{array}$ & $\rho \mathrm{CO}_{2}$ & 758 & $\mathrm{~kg} / \mathrm{m}^{3}$ & & \\
\hline $\mathrm{CO}_{2}$ viscosity & $\mu_{\mathrm{c}}$ & $6.55 \mathrm{E}-05$ & Pa-s & $6.55 \mathrm{E}-02$ & $\mathrm{cp}$ \\
\hline interfacial tension & $\sigma$ & 0.029 & $\mathrm{~kg} / \mathrm{s}^{2}$ & 29 & dynes/cm \\
\hline contact angle & $\theta$ & 0 & radians & & \\
\hline $\begin{array}{l}\text { endpoint } \mathrm{CO}_{2} \\
\text { relative } \\
\text { permeability }\end{array}$ & $k_{r c}$ & 0.4 & & & \\
\hline $\begin{array}{l}\text { endpoint water } \\
\text { (brine) relative } \\
\text { permeability }\end{array}$ & $k_{r w}$ & 1 & & & \\
\hline $\begin{array}{l}\text { residual gas } \\
\text { saturation }\end{array}$ & $S_{g r}$ & 0.1 & & & \\
\hline $\begin{array}{l}\text { irreducible water } \\
\text { saturation }\end{array}$ & $S_{w i}$ & 0.5 & & & \\
\hline
\end{tabular}

Schlumberger (2009) 
Table 4.2. Properties used in the reservoir simulation and catalog database query.

\begin{tabular}{|l|l|l|}
\hline Input parameter & Simulation & Database \\
\hline Permeability & $345 \mathrm{md}$ & $1,000 \mathrm{md}$ \\
\hline Porosity & 0.152 & 0.25 \\
\hline Kv/Kh & 0.2 & 0.1 \\
\hline Aquifer thickness & $160 \mathrm{ft}$ & $500 \mathrm{ft}$ \\
\hline Aquifer depth & $7,220 \mathrm{ft}$ & $5,000 \mathrm{ft}$ \\
\hline Aquifer radius & $74,000 \mathrm{ft}$ & $6,250 \mathrm{ft}$ \\
\hline Dip & $0.41 \mathrm{degree}$ & 0 \\
\hline Perforation interval (from bottom) & $140 \mathrm{ft}$ & $80 \mathrm{ft}$ \\
\hline Injection rate & 11.34 MMSCFD & 50 MMSCFD \\
\hline
\end{tabular}

Gas Saturation 2018-01-22.6804051 K layer: 1

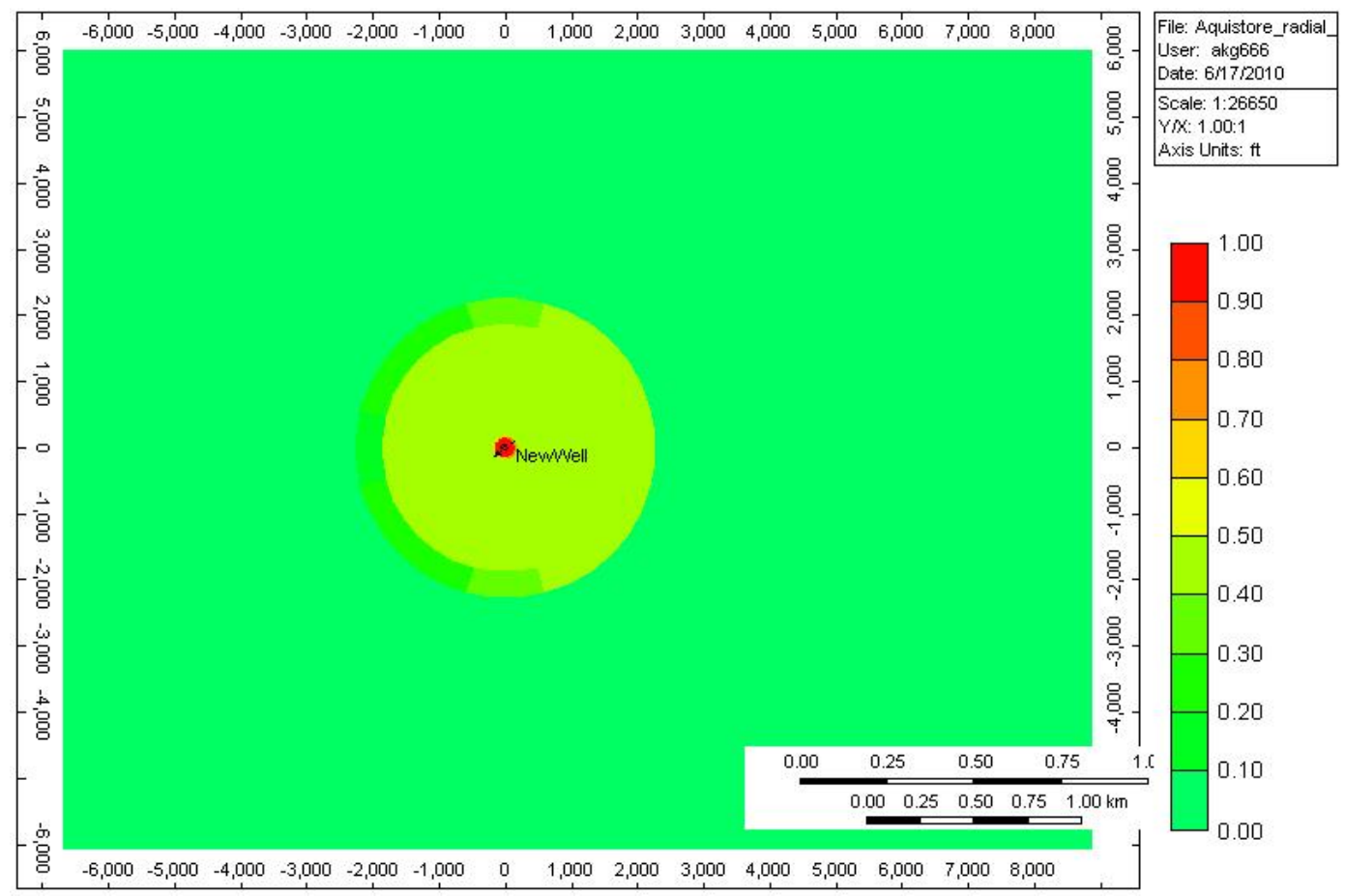

Figure 4.1. Gas saturation after 5 yrs of injection, constant pressure boundary condition. 
Gas Saturation 2028-01-21.2168056 K layer: 1

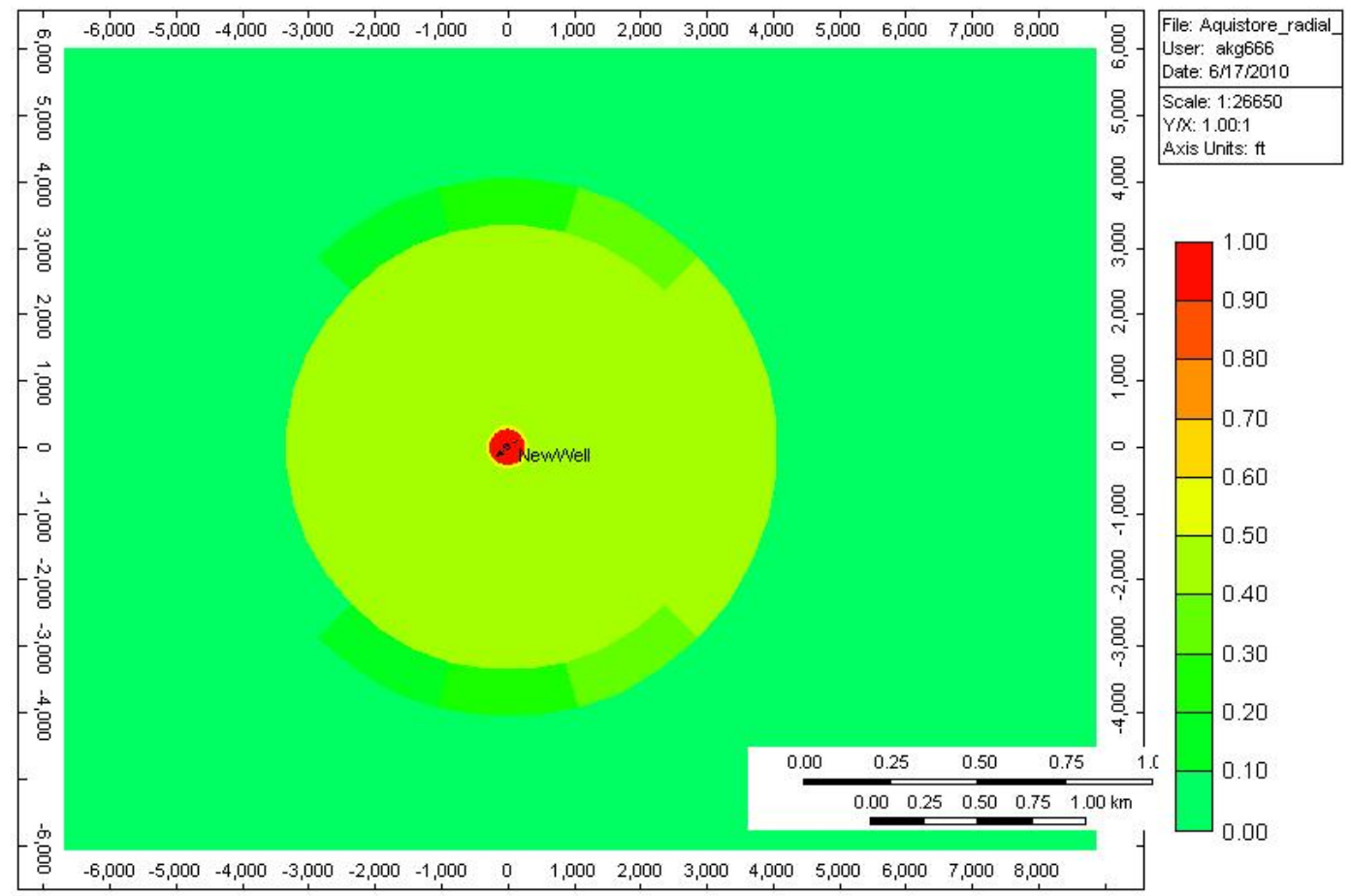

Figure 4.2. Gas saturation after 15 yrs of injection, constant pressure boundary condition.

Gas Saturation 2037-12-07.5912384 Klayer: 1

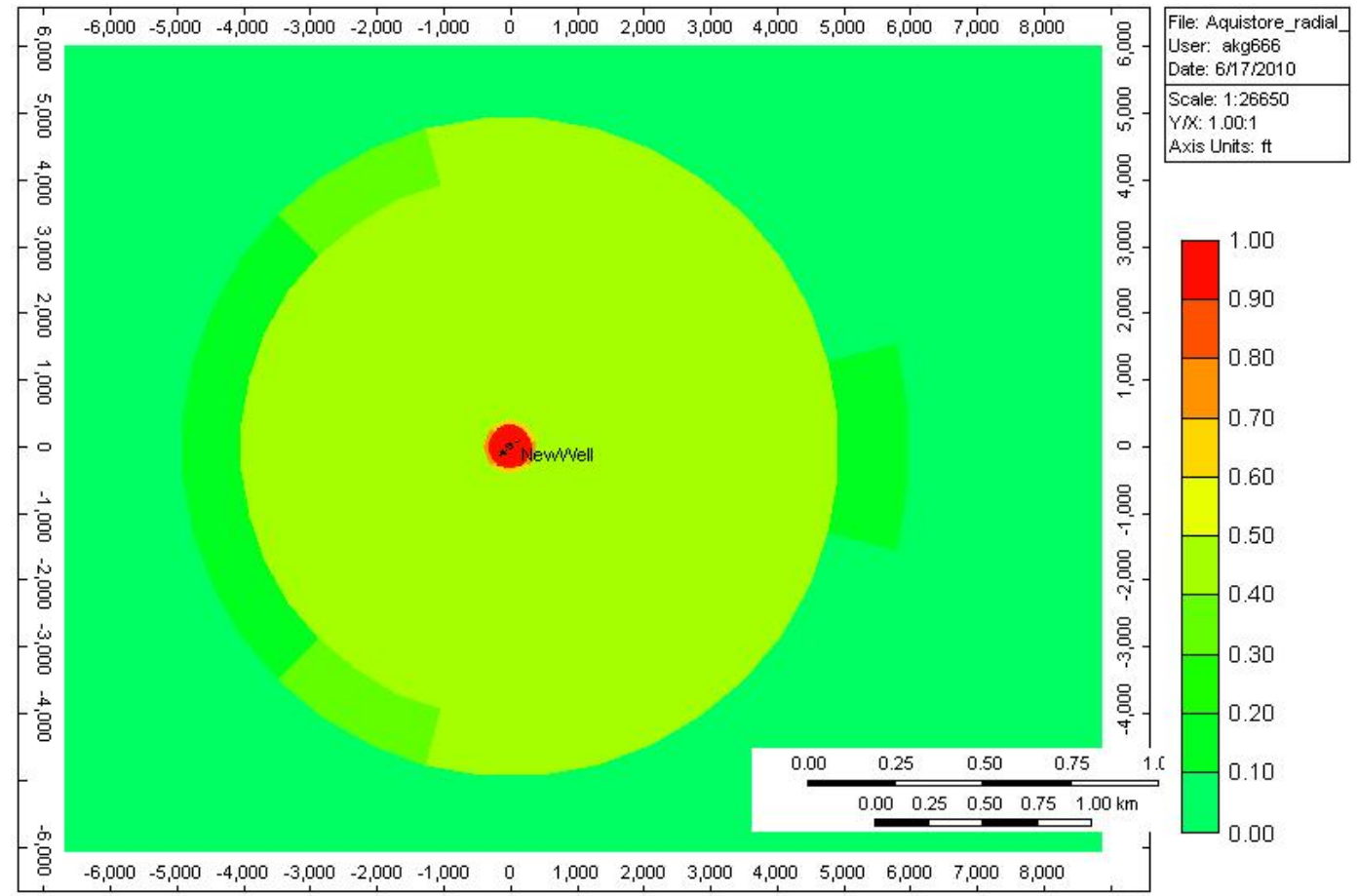

Figure 4.3. Gas saturation after 25 yrs of injection, constant pressure boundary condition. 
Gas Saturation 2062-12-20 K layer: 1

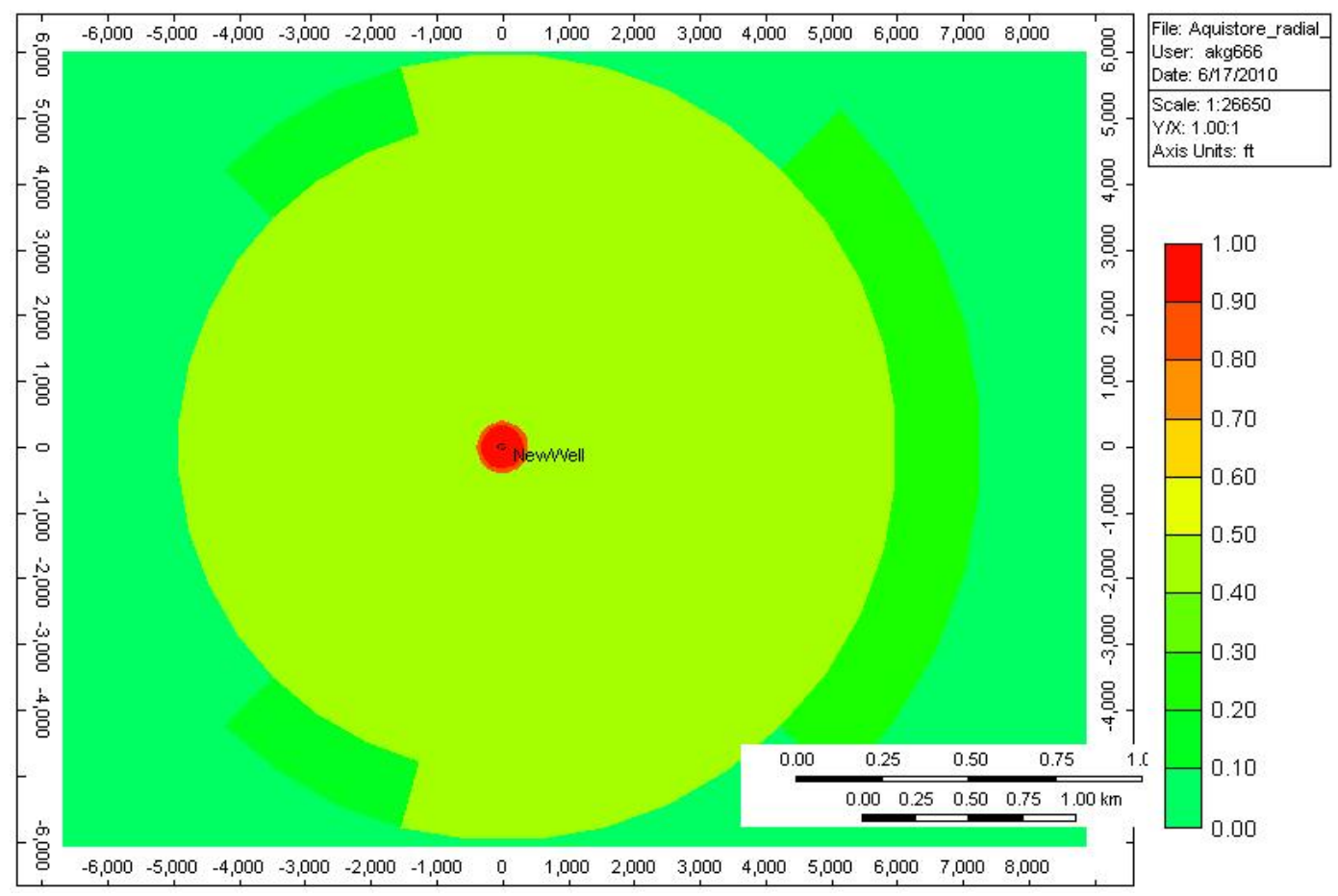

Figure 4.4. Gas saturation after 50 yrs (25 years of injection), constant pressure boundary condition.

Table 4.3. Extent of $\mathrm{CO}_{2}$ plume for different boundary conditions compared with the database catalog.

\begin{tabular}{|c|c|c|c|}
\hline \multirow{2}{*}{\begin{tabular}{c}
\multirow{2}{*}{$\begin{array}{c}\text { Time } \\
\text { (years) }\end{array}$} \\
\cline { 2 - 4 }
\end{tabular}} & \multicolumn{3}{|c|}{ Lateral extent of $\mathrm{CO}_{2}$ plume (ft) } \\
\cline { 2 - 4 } & $\begin{array}{c}|c| \\
\text { Closed } \\
\text { Boundary }\end{array}$ & $\begin{array}{c}\text { Sonstant pressure } \\
\text { Boundary }\end{array}$ & \\
\hline 5 & 2242 & 2275 & Database \\
\hline 15 & 3901 & 4065 & 2280 \\
\hline 25 & 5004 & 5169 & 5949 \\
\hline 50 & - & & 5103 \\
\hline
\end{tabular}




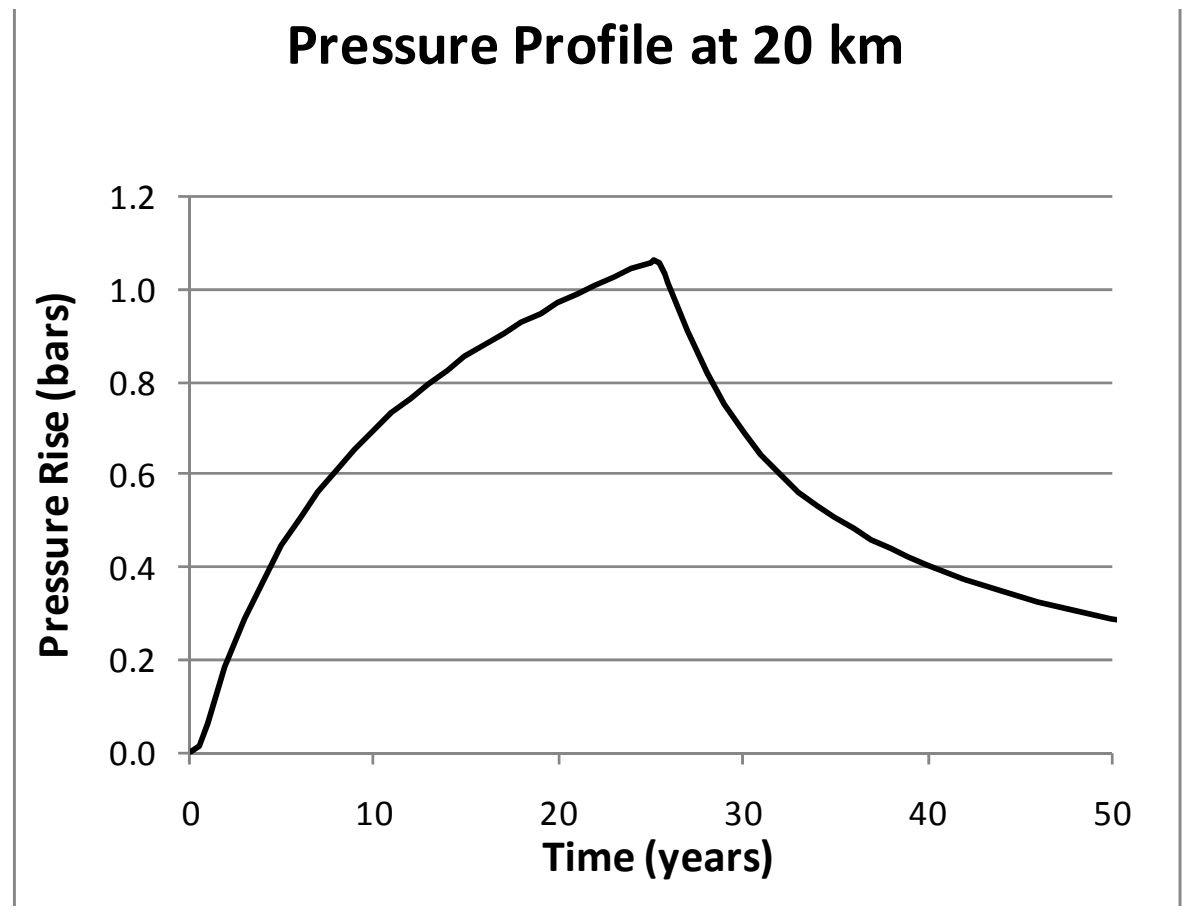

Figure 4.5. Pressure response at $20 \mathrm{~km}$ from injection well calculated using the Theis solution.

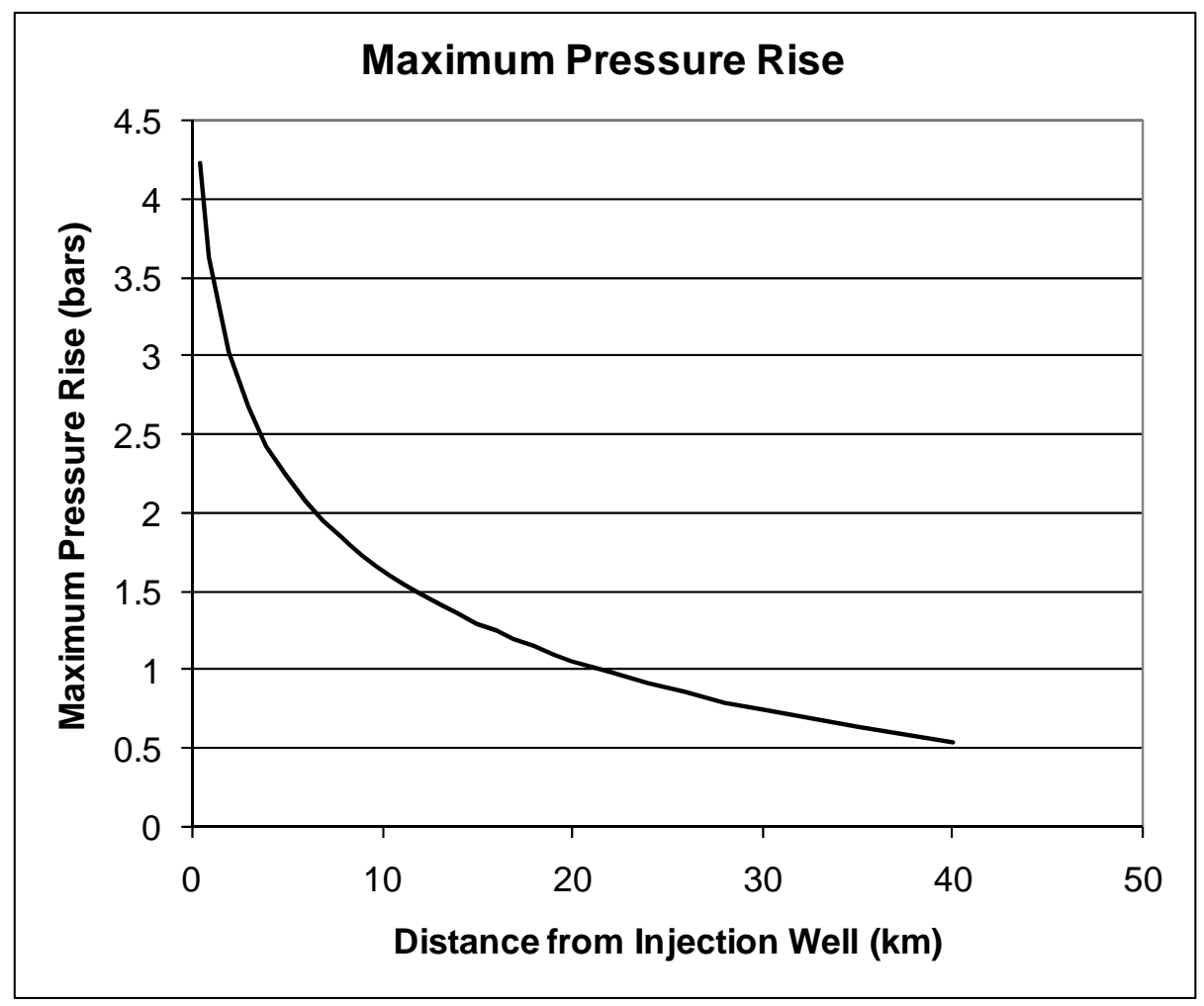

Figure 4.6. Maximum pressure rise as a function of distance from injection well calculated using the Theis solution. 


\section{CF Leakage Risk Assessment}

\subsection{Storage Region}

By the CF definition, the storage region is the subsurface region that is expected to retain the injected $\mathrm{CO}_{2}$. Any flow of $\mathrm{CO}_{2}$ or brine out of the storage region is considered leakage in the $\mathrm{CF}$ methodology. In this section we define the lateral and vertical boundaries of the storage region with consideration given to (1) the likely movements of $\mathrm{CO}_{2}$ and brine, and (2) resources that may be impacted.

Simulation studies in Section 4 indicate that the lateral region affected by $\mathrm{CO}_{2}$ and mobilized brine has a radius of much less than $20 \mathrm{~km}$ (12 mi). Our simulation results (Sec. 4) are consistent with the results in Schlumberger (2009) that predicted the plume length for a vertical well after 500 years was $4.3 \mathrm{~km}(2.7 \mathrm{mi})$. Plume size was found to be most sensitive to the range of uncertainty in irreducible water saturation and the vertical to horizontal permeability ratio. Variation of irreducible water saturation from 0.3 to 0.7 increased the plume length by approximately $1,800 \mathrm{~m}$ (1 mi) (Schlumberger, 2009). Variation of the permeability ratio from 0.1 to 0.2 resulted in an increased the plume length of approximately $1,000 \mathrm{~m}(0.62 \mathrm{mi})$. Brine pressure perturbation effects reach a maximum of about $1 \mathrm{bar}$ at a distance of $20 \mathrm{~km}(12 \mathrm{mi})$ from the injection site (Figure 4.5). This is a small change relative to the static pressure ( 200 bars) at that depth. The extent of the $\mathrm{CO}_{2}$ plume found in Section 4 plus any variations in plume extent identified in Schlumberger's simulations are also within the $20-\mathrm{km}$ radius. Therefore, a $20-\mathrm{km}(12-\mathrm{mi})$ radial distance from the injection point is defined to be the lateral boundary of the storage region.

There is the possibility of vertical leakage through the confining units associated with the Cambro-Ordovician aquifer (Downey et al., 1987; Palombi and Rostron, 2006). Vertical leakage occurs where confining beds are not locally present or the beds are extensively fractured. Leakage may also occur along regional zones of tectonic weakness or lineaments (see Section 3.3.5). Surface geochemical studies may help in identifying major fault features where leakage is occurring (Mahajan et al., 2010; Khan and Jacobson, 2008).

In the study area, the Winnipeg-Deadwood interval is encountered between $1,450(4,800 \mathrm{ft})$ and $1,850 \mathrm{~m}(6,100 \mathrm{ft})$ below mean sea level, and its thickness varies from 10 to $200 \mathrm{~m}$ (33 to $660 \mathrm{ft}$ ) (Greggs, 2000). In southern Saskatchewan, the Ordovician Winnipeg Formation is composed of sandstone and shale, while the Cambrian Deadwood Formation is composed of a basal conglomerate and interbedded sandstone, shale, and minor limestone. The stratigraphic column for the Lower Paleozoic of Manitoba and eastern Saskatchewan is shown in Figure 3.5.

As already mentioned, the Winnipeg formation is divided into two principal members, the Black Island and the Icebox Members. A North-South stratigraphic cross section of the Winnipeg throughout the Basin, using the top of the Black Island Member as a datum, shows the thinning of the Winnipeg towards north and south, from a maximum value in excess of $90 \mathrm{~m}(300 \mathrm{ft})$ in the central portion of the Basin (Chimney et al., 1990). The stratigraphy at the University of Regina geothermal well shows that the Icebox member has a thickness of about $10 \mathrm{~m}$ (33 ft) (Vigrass et al., 2007). 
The Icebox Member of the Winnipeg Formation does not appear to be a typical shale, in that the resistivity and neutron porosity measurements indicate very little clay-bound water (Schumberger, 2009). Neutron porosity readings for a typical shale at such depths and of a predominantly illitic/kaolinitic composition usually measure approximately 0.2 . In contrast, neutron porosity readings from the Icebox Member are less than this (0.14 to 0.15). This phenomenon has been elsewhere observed in deeply-buried shale where high temperature and high pressure drives the water out. Such dry shale is usually considered to be brittle and have a poor sealing capability. Furthermore, fault offset (see Section 3.3.5) may be as large as $15 \mathrm{~m}$. Note that the observations used to determine fault offset were made in the Red River area of the Williston basin along the North Dakota - South Dakota border (Sipple et al., 1995). The largest fault throws at the site could be larger or smaller, but in the absence of site-specific information, throws large enough to fully offset the Icebox should be anticipated. Given the possibility that the Icebox shale is brittle and fractured, and the possibility of a complete offset of this 10-m thick layer by faults, a conservative assumption is that there could be vertical flow of $\mathrm{CO}_{2}$ past the Icebox shale.

The next potential aquitard above the Icebox shale is the Lake Alma member of the Herald Formation (Figure 3.5). This unit is an anhydrite, a common sealing lithology, which has a

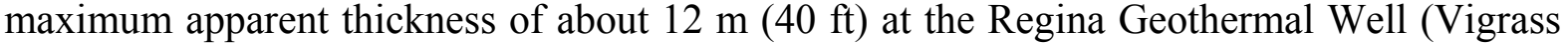
et al., 2007). Because this is less than potential fault offset, this seal could be compromised by faulting. Sorrensen et al. (2009) indicate that the Stony Mountain Formation, which sits on the Herald Formation, is a seal for the Washburn Study Area of the Williston Basin in North Dakota. However, the Gunton and Coronach (part of Herald Formation) anhydrites and the Gunn member (calcareous shale and fossiliferous limestone) pinch out south of Regina (Norford et al., 2008), making this seal less reliable.

The Ashern Formation, at the base of the Devonian stratigraphic column, consists of dolostone and shale and was identified by Nicolas and Barchyn (2009) as a potential seal. However, this layer is approximately $10 \mathrm{~m}(33 \mathrm{ft})$ thick in the Regina area and was interpreted locally as a dolostone (Vigrass et al., 2007). The local shale content and quality of this unit are not known. Given the current information, this unit cannot be relied upon as a seal. However, if additional information is collected confirming a shale lithology, it may be possible to assign the Ashern as the upper sealing formation for the storage zone.

The next aquitard above this is the Prairie Evaporite, which was described by Palombi and Rostron (2006) as one of the most effective aquitards in the Williston Basin. This formation was also identified as an aquitard by Bachu and Hitchon (1996), although it is not a regional seal because the Prairie Evaporite is not present over a large portion of the basin. The Prairie Evaporite is approximately $100 \mathrm{~m}(330 \mathrm{~m})$ thick in the Regina Geothermal Well stratigraphy (Vigrass et al., 2007) and thickens or maintains thickness up-dip and along strike for more than $30 \mathrm{~km}(19 \mathrm{mi})$. In the down-dip direction the formation thins, but maintains a thickness in excess of $50 \mathrm{~m}(160 \mathrm{ft})$ as far as $30 \mathrm{~km}(19 \mathrm{mi})$ down-dip (TGI II Prairie Evaporite isopach). Therefore, this aquitard is expected to retain $\mathrm{CO}_{2}$ and prevent upward brine flow even in the presence of faulting. The storage region relative to the stratigraphy is shown in Figure 5.1.

The potash resource, when present, is found in the Prairie Evaporite. According to Nicolas and Barchyn (2009), potash zones are generally found near the top of the formation, which is also supported by the information presented in Norford et al. (2008). Therefore, assigning the 
upper stratigraphic limit of the storage region to be the base of the Prairie Evaporite should not impact the potash resource.

Note that the analysis used to arrive at the Prairie formation as the upper boundary of the storage region is conservative. The fact that the Icebox, Herald and Ashern confining layers are thin relative to the potential fault throw does not mean that these units would necessarily leak, and in fact they could be excellent seals. This judgment is linked to a data point (for the $15 \mathrm{~m}$ (50 ft) fault throw) from a location within the Williston Basin, but far from the study area. Local information on faulting was not available. Investigations of shale seal reliability from the petroleum industry indicates that thinner, more deformed and faulted caprocks are more likely to leak than thicker, relatively undisturbed caprocks (Grunau, 1987). Therefore, there does appear to be a connection between faulting, seal thickness, and leakage through a caprock. On the other hand, there is no question that faults can also have extremely low permeabilities and can be part of an effective seal. We emphasize that the purpose of defining the storage region in the $\mathrm{CF}$ approach is to define what constitutes leakage. By the definition adopted here, leakage upward past the thinner confining layers would not be considered leakage; only upward migration into and beyond the Prairie evaporite would be considered vertical leakage. 


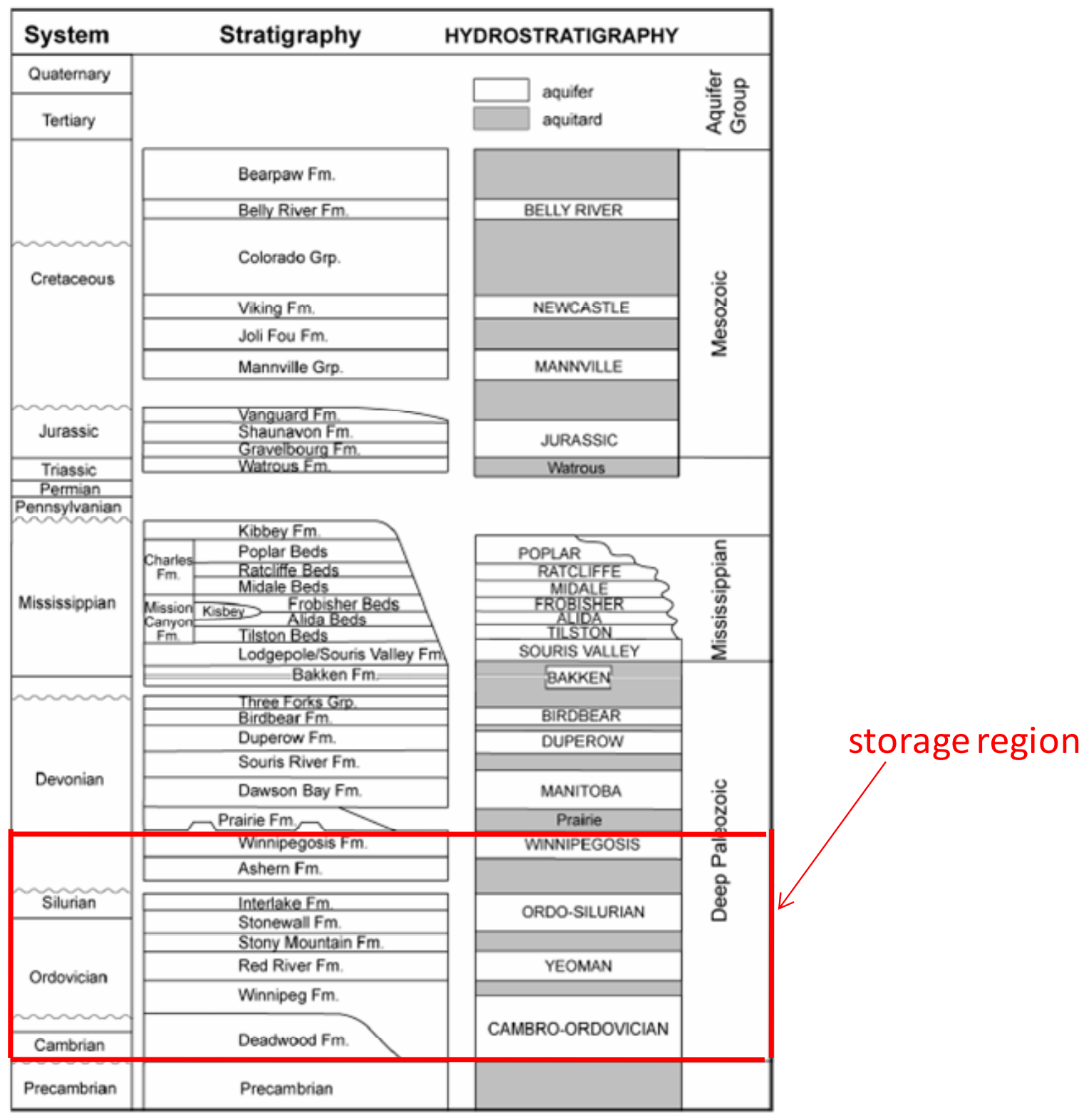

Figure 5.1. Stratigraphy with storage region indicated.

\section{2 $\mathrm{CO}_{2}$ and Brine Leakage Likelihood and Impacts}

\subsubsection{Wells}

Potash development in the area of Regina is located at Belle Plaine (Berenyi, 2007). The associated brine disposal well is more than $40 \mathrm{~km}$ southwest of the potential injection point. The Encanto Potash Corporation website provides additional information on wells in the general area of Regina. The data from these wells have been used to evaluate their Muscowpetung Prospect northeast of Regina. Oil and gas development in Saskatchewan is focused in the Weyburn area southeast of Regina and in western Saskatchewan (Saskatchewan Ministry of Energy and Resources, 2008). 
The information available on wells indicates that the nearest well along a northeasterly path is about $40 \mathrm{~km}$ from the injection point (Schlumberger, 2009). This is an old well constructed in or prior to 1956. Because of its age, information about the well may be lacking; the last log was performed in 1956. On the other hand, it is $40 \mathrm{~km}$ away from the injection point and the plume is not expected to migrate that far. There are two wells closer than this; the University of Regina geothermal well is $13 \mathrm{~km}(8 \mathrm{mi})$ south of the nominal injection site and was constructed and logged in 1979 (Schlumberger, 2009). The well is documented in Vigrass et al (2007). The other well is approximately $25 \mathrm{~km}$ southeast of the nominal injection point. This well was constructed in 1999 or earlier (Schlumberger, 2009). Additional wells identified by Encanto Potash Corporation lie about $25 \mathrm{~km}$ (16 mi) east of the injection point (Well - Pheas Chev Tenn Regina, 6-29-18-16W2) and $30 \mathrm{~km}$ northwest (Well - Imperial Lumsden, 11-11-20-22W2). The intensity of deep-well development increases moving southeast toward known petroleum resources near Weyburn. All remaining wells are $40 \mathrm{~km}$ (25 mi) or more away from the injection point, which is nearly ten times as far as the plume is expected to migrate.

The results given in Section 4.1 indicate that the pressure rise at $20 \mathrm{~km}(12 \mathrm{mi})$ is less than 1 bar; the maximum pressure rise at $13 \mathrm{~km}(8 \mathrm{mi})$ is not much more at 1.4 bars (Figure 4.6 ). Several mitigating factors exist to limit the amounts of brine that can flow up a borehole, e.g., thief zones, effects of high density on upward brine flow, low permeability of well cement, presence of mud, etc. (e.g. see, Nicot et al., 2009). Furthermore, brine would have to leak upwards nearly $2 \mathrm{~km}(1.2 \mathrm{mi})$ to reach potable water. The buoyancy effect and the lower viscosity of $\mathrm{CO}_{2}$ result in greater leakage potential for $\mathrm{CO}_{2}$ than brine. However, the distance to surrounding wells relative to the predicted size of the $\mathrm{CO}_{2}$ plume means that well leakage through existing wells is highly unlikely.

Because of the sparse well development, large distances between the proposed injection site and other wells, and the scarcity of wells along the expected migration path, the likelihood of brine and $\mathrm{CO}_{2}$ leakage via wells is near zero. Because of this zero likelihood, no modeling of well flow to estimate impacts under the CF methodology is warranted. However, future development of potash solution mining and related fluid disposal wells within the storage region footprint could result in greater likelihood of $\mathrm{CO}_{2}$ and brine well leakage out of the storage region.

\subsubsection{Faults}

Local information about faults is indirect. The main sources of information are from gravity and magnetic anomaly lineaments reported by Li and Morozov (2007). If these lineaments represent major faults, then there is one fault that lies about $2 \mathrm{~km}(1.2 \mathrm{mi})$ away from the nominal injection point. Other potential faults are farther away than $10 \mathrm{~km}(6 \mathrm{mi})$. A study concerning the same stratigraphic section on the boundary between North and South Dakota indicates that fault throw on major faults is about $15 \mathrm{~m}(50 \mathrm{ft})$ or less in the Ordovician decreasing to below detection by the Upper Devonian (Sipple et al., 1995). Applying these results to the vicinity of Regina is quite speculative, but suggests that because the Prairie

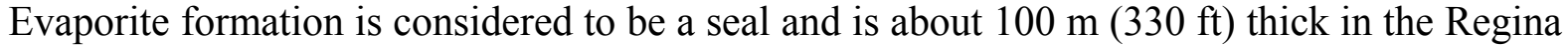
area, faults are not expected to entirely offset the seal. Still, faults through the Prairie Evaporite could conceivably create transmissive damage zones even if they are not fully offsetting. However, the Prairie contains halite. The propensity of this lithology to 
rheological flow suggests it would tend to seal fractures. Consequently the Prairie Evaporate is likely to be able to prevent $\mathrm{CO}_{2}$ or brine from migrating up a fault.

Because of a lack of information concerning faults in the area, there is a small potential for $\mathrm{CO}_{2}$ and brine to migrate to higher levels through the Prairie Evaporite, such as via conduits created by local dissolution along faults (Haidl et al., 2004). Such migration would constitute leakage (flow across the boundary of the storage region) with potential impact on potash resources in the hydrocarbon and mineral resource (HMR) compartment (see Appendix A) However, fluids migrating upsection above the Prairie would encounter the Bakken Aquitard (Mississippian), which is identified as a regional seal by Bachu and Hitchon (1996). The Watrous aquitard (Jurassic) lies above the Bakken, also identified as a regional seal for the Weyburn $\mathrm{CO}_{2}$ project (Khan et al., 2004). Finally, there is approximately $500 \mathrm{~m}(1600 \mathrm{ft})$ of uninterrupted Cretaceous shales that lie above the Watrous, with a base about $700 \mathrm{~m}$ (2300 $\mathrm{ft}$ ) below the ground surface. The Cretaceous shales cap the Mannville aquifer (Vigrass et al., 2007). The water quality profile shows that the Mannville aquifer has a minimum TDS of $10,000 \mathrm{mg} / \mathrm{L}$ (Palombi, 2008), which exceeds the Saskatchewan water quality objectives for drinking water $(1,500 \mathrm{mg} / \mathrm{L})$ and agricultural use $(3,500 \mathrm{mg} / \mathrm{L})($ Saskatchewan Environment 2006a, 2006b). The Mannville aquifer is also described as a saline aquifer relative to potable water contained in aquifers at shallower depths in the Yorkton water quality report (Maathius and Simpson, 2006; Yorkton is about $180 \mathrm{~km}$ (110 mi) northeast of Regina). Therefore, the main impact of $\mathrm{CO}_{2}$ leakage above the Prairie Evaporite is that the (potential) potash resource would be locally affected. There would be no impact for brine leakage above the Prairie Evaporite because it is expected to be contained at some point below the Cretaceous shales, where groundwater is naturally saline. As was the case for well leakage, the low likelihood of fault leakage above the Prairie Evaporite obviates the need for modeling impacts of leakage up wells at this site.

\subsection{Leakage Risk}

In the $\mathrm{CF}$, the $\mathrm{CO}_{2}$ and brine leakage risks are defined as the product of the probability of leakage out of the storage region and the consequences of that leakage. For $\mathrm{CO}_{2}$ injected at the proposed rates for the duration of the project, including 25 years post-injection, the likelihood of leakage beyond the $20-\mathrm{km}(12 \mathrm{mi})$ radius of the storage region is too small to calculate and can be assumed to be zero because of low driving forces for lateral migration. The consequences of lateral $\mathrm{CO}_{2}$ leakage are also estimated to be minimal in the storage formation, therefore, the lateral $\mathrm{CO}_{2}$ leakage risk is found to be de minimis. The likelihood of upward $\mathrm{CO}_{2}$ leakage beyond the upper storage region boundary is also very low; however, this is more uncertain because of a lack of site-specific information on faults, local variations in stratigraphic thickness, hydrologic property variations, and potential for future development of potash brine disposal wells that could penetrate the $\mathrm{CO}_{2}$ plume. The potential for $\mathrm{CO}_{2}$ leakage through existing wells is considered to be near zero because of the sparse development of wells and distances to other wells. The principal consequences for $\mathrm{CO}_{2}$ leakage through faults is that the potential potash resource would be locally affected. The consequences of $\mathrm{CO}_{2}$ leakage through potential future wells may be more significant because it could result in $\mathrm{CO}_{2}$ entering the potable water supply or the atmosphere. However, such a scenario is also more likely to be identified and mitigated through remedial actions before significant impact occurs. In summary, the overall $\mathrm{CO}_{2}$ leakage risk is considered to be very low but subject to several uncertainties that can be addressed by future characterization activities (see Sec. 6). 
For brine leakage risk, the probability for leakage beyond the $20-\mathrm{km}$ (12 mi) radius laterally is high; however, the magnitude is small and the consequences negligible. Because brine migration into the potash resource also carries no known consequence, upward brine leakage risk for invading this region is also negligible. The only brine leakage risk that needs to be assessed is leakage into potable water supplies or to the ground surface. As with vertical $\mathrm{CO}_{2}$ leakage likelihood, upward brine leakage through faults and existing wells will be very low to negligible. The likelihood of leakage through potential future wells may be different for brine than $\mathrm{CO}_{2}$ because the driving force for brine migration covers a broader area than the $\mathrm{CO}_{2}$ plume. On the other hand, the driving force for brine migration decays following the 25year $\mathrm{CO}_{2}$ injection period, reducing the magnitude of brine migration at longer times. Overall, we find the brine leakage risk to be even lower than the $\mathrm{CO}_{2}$ leakage risk and this leakage risk is affected by fewer uncertainties. 


\section{Summary and Recommendations}

Based on existing information and inferences from regional data, the potential site appears to have excellent potential for safe, long-term storage of $\mathrm{CO}_{2}$ in the deep, high-salinity brines of the Winnipeg/Deadwood aquifers at the base of the Williston Basin. Although there is a considerable amount of regional information concerning the Williston Basin from the standpoint of hydrogeology, mineral resources, and other $\mathrm{CO}_{2}$ sequestration activities, the lack of local, site-specific information to help characterize the site leads to some uncertainty about the project and motivates more data collection. For example, it is possible that some of the regional behavior concerning interactions between aquifers may result in underestimating the local seal integrity.

The major data needs concern faulting and fault offset, seal integrity, and quantification of residual $\mathrm{CO}_{2}$ saturation. Furthermore, an assessment of future development of mineral resources is needed, in particular, potash solution mining. Because the storage region goes to the base of the Prairie Evaporite and potash is typically found in upper members of this unit, this assessment needs to consider the likelihood that solution mining activities may fully penetrate the Prairie, as distinct from activities confined to the upper members. In addition, solution mining often involves deep disposal wells that would have to be built to withstand potential interactions with acidic $\mathrm{CO}_{2}$ and brine mixtures if constructed within the footprint of the storage region. The following recommendations are made to improve confidence in the ability of the potential project to successfully sequester $\mathrm{CO}_{2}$ :

Main Recommendations:

1. Obtain high-resolution 3D seismic information to help identify the location and offset of local fault structures across the Ashern and Prairie Evaporite Formations. High resolution is required because it is necessary to identify faults that completely offset potential sealing strata on the order of $10 \mathrm{~m}$ thick. Also evaluate potential variations in thickness in the Prairie Evaporite that may have resulted from localized dissolution (Haidl et al., 2004; Prugger et al., 2004).

2. Collect mineralogical data for the Ashern Formation to determine the shale content. Determine the hydration state of shale in the Ashern Formation to evaluate if dehydration may have occurred as appears to be the case for the Icebox shale.

3. Perform pre-injection hydrologic testing to look for leaking wells and/or faults; monitor wells for water level changes in Winnipegosis and Manitoba aquifers to check for seal integrity (Birkholzer et al., 2009; Zeidouni et al., 2010).

4. Perform imbibition relative permeability experiments on core samples from the Cambro-Ordovician aquifer. Tests should be performed starting from irreducible brine saturation $\left(S_{w i}\right)$ to constrain the relative permeability for the brine displacing $\mathrm{CO}_{2}$ process and residual $\mathrm{CO}_{2}$ saturation. These will complement the existing relative permeability data for $\mathrm{CO}_{2}$ displacing brine reported by Schumberger (2009).

5. Perform detailed simulations (e.g., with TOUGH2 (Pruess et al., 1999) and iTOUGH2 (Finsterle, 1999) of $\mathrm{CO}_{2}$ plume size, shape, and migration path, including uncertainty in dip, horizontal permeability distribution, regional flow, and fault effects, to develop probabilistic estimates for plume evolution and interactions with faults and wells. Development and application of analytical methods for both plume 
evolution and pressure response are recommended for comparison with numerical results.

6. Evaluate the potential for potash resource development within the affected storage region and $\mathrm{CO}_{2}$ plume footprint. This evaluation should include the likelihood that such development may fully penetrate and compromise the sealing characteristic of the undisturbed Prairie Evaporite formation.

Additional Recommendations (having lower priority):

7. Collect local hydrogeochemical and, in particular, stable isotope data to better evaluate the likelihood of long-term containment of $\mathrm{CO}_{2}$ and brine by seals in the Winnipeg, Stony Mountain, and Prairie Evaporite formations (Wittrup, 1988; Heath et al., 2009). Cross-borehole tracer tests across sealing intervals may also provide valuable data on seal integrity.

8. Perform laboratory permeability and drainage capillary pressure tests on core samples from sealing intervals.

9. Imbibition relative permeability experiments starting at elevated brine saturations (e.g., $0.25+0.75 S_{w i}, 0.5+0.5 S_{w i}$ and $0.75+0.25 S_{w i}$ ) would help to define hysteresis effects, especially on residual $\mathrm{CO}_{2}$ saturation (Doughty, 2007). Relative permeability tests from overlying aquifers may also be valuable for evaluating scenarios in which leakage occurs through overlying sealing formations (Winnipeg Icebox shale, Stony Mountain/Herald anhydrite).

10. Perform laboratory tests on core samples from the Cambro-Ordovician aquifer to quantify rock compressibility. 


\section{References}

Bachu, S. and B. Hitchon. 1996. Regional-Scale Flow of Formation Waters in the Williston Basin, AAPG Bull., V.80, No. 2, pp. 248-264.

Bennion, B. and Bachu, S. 2005. Relative permeability characteristics for supercritical $\mathrm{CO}_{2}$ displacing water in a variety of potential sequestration zones in the Western Canada Sedimentary Basin. SPE 95545, p. 1-15.

Berenyi, J. 2007. Saskatchewan's Potash Industry, Saskatchewan Energy and Resources Presentation.

http://www.er.gov.sk.ca/adx/aspx/adxGetMedia.aspx?DocID=5837,5833,5832,5352,36 $\underline{32,3538,3385,5460,2936, \text { Documents \&MediaID=18784\&Filename }=\mathrm{OH} 2007 \text { TS4 Ber }}$ enyi.pdf

Birkholzer, J.T., Q. Zhou and C.F. Tsang. 2009. Large-Scale Impact of $\mathrm{CO}_{2}$ Storage in Deep Saline Aquifers: A Sensitivity Study on Pressure Response in Stratified Systems, International Journal of Greenhouse Gas Control, Vol. 3, pp. 181-194.

Brunskill, B. 2006. Discussion of an Option for Geological Storage of Used Nuclear Fuel Beneath the Williston Basin of Southern Saskatchewan, in Summary of Investigations 2006, Volume 1, Saskatchewan Geological Survey, Sask. Industry Resources, Misc Report 2006-4.1, CD-ROM, Paper A4, 8p.

Bunge, R. 2001. Midale Reservoir Fracture Characterization Using Integrated Well and Seismic Data, Weyburn Field, Saskatchewan, AAPG Annual Meeting, Denver, Colorado, June 3-6 2001.

Burwash, R.A., C.R. McGregor and J. Wilson. 2008. Precambrian Basement Beneath the Western Canada Sedimentary Basin; in Geological Atlas of the Western Canada Sedimentary Basin, G.D. Mossop and I. Shetsen (comp.), Canadian Society of Petroleum Geologists and Alberta Research Council, Special Report 4, URL http://www.ags.gov.ab.ca/publications/wcsb_atlas/a_ch05/ch_05.html.

Chimney P.J., C.E. Treska and C.A. Wolosin. 1990. Richardton/Taylor Fields - Williston Basin, North Dakota.

http://search.datapages.com/data/specpubs/fieldst4/images/a025/a0250001/0400/04210. pdf

Doughty, C. 2007. Modeling Geologic Storage of Carbon Dioxide: Comparison of NonHysteretic and Hysteretic Characteristic Curves, Energy Conversion Management, Vol. 48, Issue 6, June 2007, pp. 1768-1781.

Downey, J.S., J.F. Busby and G.A. Dinwiddie. 1987. Regional aquifers and petroleum in the Williston Basin region of the United States. In: M.W. Longman ed., Williston Basin: Anatomy of a Cratonic Oil Province, Rocky Mountain Association of Geologists, p. 299-312.

Downey J.S. and G.A. Dinwiddie. 1988. The Regional Aquifer System Underlying the Northern Great Plains in Parts of Montana, North Dakota, South Dakota, and Wyoming - Summary, USGS Professional Paper 1402-A. 
Encanto Potash Corporation website:

http://www.encantopotash.com/english/projects1/firstnations/muscowpetung/overview/ default.aspx

Ferguson, G.A.G., R.N. Betcher, and S.E. Grasby. 2006. Hydrology of the Winnipeg Formation in Manitoba, Canada. Hydrogeology Journal. 15, pp. 573-587. November 2006.

Finsterle, S. 1999. iTOUGH2 User's Guide, Report LBNL-40040, Lawrence Berkeley National Laboratory, Berkeley, Calif.

Golder Associates. 2007. Air Quality Assessment of the Refinery - Upgrader Complex Expansion Project Section V and Revamps, for the Consumers' Co-operative Refineries Limited, Regina, Saskatchewan, 07-1331-0003. http://www.environment.gov.sk.ca/2007-184EIA(ProjectProposalAppendixA1).

Gorecki, C.D., J.A. Sorensen, E. Steadman and J.A. Harju. 2009. $\mathrm{CO}_{2}$ Storage Risk Minimization through Systematic Identification and Assessment of Faults: A Williston Basin Case Study, Energy Procedia 1. pp. 2887-2894.

Greggs, D.H. 2000. The Stratigraphy, Sedimentology, and Structure of the Lower Paleozoic Deadwood Formation of Western Canada, Master of Science Thesis, University of Calgary, Department of Geology and Geophysics.

Grunau, H.R. 1987. A Worldwide Look at the Caprock Problem, Journal of Petroleum Geology, 10(3) pp. 245-266.

Haidl, F.M., M. Yurkowski, S.G. Whittaker, L.K. Kreis, C.F. Gilboy and R.B. Burke. 2004. The Importance of Regional Geological Mapping in $\mathrm{CO}_{2}$ Storage Site Characterization: Examples from the IEA Weyburn $\mathrm{CO}_{2}$ Monitoring and Storage Project. In: Proceedings of the $7^{\text {th }}$ International Conference on Greenhouse Gas Control Technologies. Volume 1: Peer-Reviewed Papers and Plenary Presentations, Vancouver, BC, September 5-9, 2004.

Heath, J., B. McPherson, F. Phillips, S. Cooper and T. Dewers. 2009. Natural Helium as a Screening Tool for Assessing Caprock Imperfections at Geologic $\mathrm{CO}_{2}$ Storage Sites, Energy Procedia 1, pp. 2903-2910.

Kent, D.M. and J.E. Christopher. 2008. Geological history of the Williston Basin and Sweetgrass River Arch; in Geological Atlas of the Western Canada Sedimentary Basin, G.D. Mossop and I. Shetsen (comp.), Canadian Society of Petroleum Geologists and Alberta Research Council, Special Report 4, URL

$<$ http://www.ags.gov.ab.ca/publications/wcsb_atlas/atlas.html $>,[6 / 7 / 2010]$. August 20, 2008.

Khan, S.D. and S. Jacobson. 2008. Remote Sensing and Geochemistry for Detecting Hydrocarbon Microseepages, Geological Society of America Bulletin 2008;120;96105.

Khan, D.K. and B.J. Rostron. 2004. Regional Hydrogeological Investigation Around the IEA Weyburn $\mathrm{CO}_{2}$ Monitoring and Storage Project Site; in Rubin, E. S., D. W. Keith, and C. F. Gilboy (eds.), Proceedings of the 7th International Conference on Greenhouse Gas Control Technologies (GHGT-7), Sept. 5-9, 2004, Vancouver, Canada, Volume 1: Peer-Reviewed Papers and Plenary Sessions, Elsevier, UK, p741-750. 
Khan, D.K., B.J. Rostron, Z. Margitai and D. Carruthers. 2006. Hydrodynamics and Petroleum Migration in the Upper Ordovician Red River Formation of the Williston Basin, Journal of Geochemical Exploration 89 (2006) 179-182.

Li, J. and I. Morozov. 2007. Geophysical Investigations of the Precambrian Basement of the Williston Basin in South-Eastern Saskatchewan and South-Western Manitoba, Final Project Report, Williston Basin Targeted Geoscience Initiative II. February 2007.

Lyatsky, H., D. Pana, R. Olson and L. Godwin. 2003. Mapping Basement Faults with Gravity and Magnetic Data in Northern Alberta, Canadian Society of Petroleum Geologists Conference/Canadian Society of Exploration Geologists, June 2-6 2003, Calgary, Altberta.

Maathius, H. and M. Simpson. 2006. Groundwater Resources in the Yorkton Aquifer Management Plan Area: Final Report, Saskatchewan Research Council, Environment and Forestry Division, SRC Publication No. 10419-1E06, June 2006. http://www.swa.ca/Publications/Documents/GroundwaterResourcesintheYorktonAquif erManagementPlan.pdf

Mahajan, S., V. Walia, B.S. Bajwa, A. Kumar, S. Singh, N. Seth, S. Dhar, G.S. Gill and T.F. Yang. 2010. Soil-gas radon/helium surveys in some neotectonic areas of NW Himalayan foothills, India, Nat. Hazards Earth Syst. Sci., 10, 1221-1227, 2010, www.nat-hazards-earth-syst-sci.net/10/1221/2010/.

Nicolas, M.P.B. and D. Barchyn. 2009. Williston Basin Project (Targeted Geoscience Initiative II): Summary Report on Paleozoic Stratigraphy, Mapping and Hydrocarbon Assessment, Southwestern Manitoba, Geoscientific Paper GP2008-2, Manitoba Geological Survey, January 2009.

Nicot, J.-P., C.M. Oldenburg, S.L. Bryant and S.D. Hovorka. 2009. Pressure perturbations from geologic carbon sequestration: Area-of-review boundaries and borehole leakage driving forces. In: Gale, J., Herzog, H., and Braitsch, J. (eds), Greenhouse Gas Control Technologies 9, Proceedings of the 9th International Conference on Greenhouse Gas Control Technologies (GHGT-9), 16-20 November 2008, Washington DC, US, Energy Procedia, February 2009, 1: 47-54.

Norford, B.S., F.M. Haidl, R.K. Bezys, M.P. Cecile, H.R. McCabe and D.F. Paterson. 2008. Middle Ordovician to Lower Devonian Strata of the Western Canada Sedimentary Basin, in Geological Atlas of the Western Canada Sedimentary Basin, G.D. Mossop and I. Shetsen (comp.), Canadian Society of Petroleum Geologists and Alberta Research Council, Special Report 4, URL $<$ http://www.ags.gov.ab.ca/publications/wcsb_atlas/atlas.html $>,[6 / 7 / 2010]$. August 20, 2008 .

Oldenburg, C.M., S.L. Bryant and J.-P. Nicot. 2009. Certification Framework Based on Effective Trapping for Geologic Carbon Sequestration, Int. J. of Greenhouse Gas Control 3, 444-457, LBNL-1549E.

Oldenburg, C.M., and J.L. Lewicki. 2006. On leakage and seepage of $\mathrm{CO}_{2}$ from geologic storage sites into surface water, Environmental Geology, 50(5), 691-705, LBNL-59225.

Palombi, D.D. 2008. Regional Hydrogeological Characterization of the Northeastern Margin in the Williston Basin. University of Alberta, Unpublished M.Sc. Thesis. 
Palombi, D. and B. Rostron. 2006. Regional Hydrochemistry of Lower Paleozoic Aquifers in the Northern Portion of the Williston Basin, Saskatchewan-Manitoba, in Gilboy, C.F. and S. G. Whittaker (eds.), Saskatchewan and Northern Plains Oil \& Gas Symposium 2006, Saskatchewan Geological Society Special Publication 19, p201-209.

Penner, L. 2006. Evidence Linking Surface Lineaments, Deep-Seated Faults and FractureControlled Fluid Movement in the Williston Basin, 14th Williston Basin Petroleum Conference \& Prospect Expo, May 7-9, 2006, Minot ND.

Pomeroy, J.W., D. de Boer and L.W. Martz. 2005. Hydrology and Water Resources of Saskatchewan, Center for Hydrology, Report \#1, University of Saskatchewan, Saskatoon, Saskatchewan.

Price, L. 1994. Basin Richness and Source Rock Disruption - A Fundamental Relationship? Journal of Petroleum Geology, vol. 17(1), January 1994, pp. 5-38.

Price, R.A. 2008. Cordilleran Tectonics and the Evolution of the Western Canada Sedimentary Basin; in Geological Atlas of the Western Canada Sedimentary Basin, G.D. Mossop and I. Shetsen (comp.), Canadian Society of Petroleum Geologists and Alberta Research Council, Special Report 4, URL http://www.ags.gov.ab.ca/publications/wcsb_atlas/a_ch02/ch_02.html

Pruess, K., C.M. Oldenburg and G.J. Moridis. 1999. TOUGH2 User's Guide Version 2. E. O. Lawrence Berkeley National Laboratory Report LBNL-43134, November 1999.

Prugger, A., B. Nemeth and T. Danyluk. 2004. Detailed 3D Seismic Imaging of Paleozoic Karst/Collapse Disturbances in Saskatchewan: Case Study from the Potash Belt, Canadian Society of Exploration Geologists National Convention, 2004, Calgary, May $10-13$.

Ridgley, J.L. 2002. Regional Geochemical Study of the Upper Cretaceous Shallow Biogenic Gas System in Saskatchewan, Alberta, and Montana - Application of Isotope and Compositional Systematics to Understanding the Distribution of Gas Reservoirs, in Summary of Investigations, 2002, Vol. 1, Saskatchewan Geological Survey, Sask. Industry and Resources, Misc. Report, 2002-4.1, p. 143-150.

Rostron, B.J. and C. Holmden. 2000. Fingerprinting Formation Waters Using Stable Isotopes, Midale Area, Williston Basin, Canada, Journal of Geochemical Exploration 69-70, 219-223.

Ruse, D. 2004. $\mathrm{CO}_{2}$ Disposal Potential in the Deep Subsurface of Southeast Saskatchewan, Prepared for Helix Geological Consultants, LTD by Cavern Engineering LTD. April 2004.

Saskatchewan Environment. 2006a. Saskatchewan's Drinking Water Quality Standards and Objectives, EPB 207. http://www.saskh20.ca/MyDrinkingWater.asp

Saskatchewan Environment. 2006b. Surface Water Quality Objectives, EPB 356. July 2006. http://www.environment.gov.sk.ca/adx/aspx/adxGetMedia.aspx?DocID=768,760,253,9 $\underline{4,88, \text { Documents } \& \text { MediaID }=332 \& \text { Filename }=\text { Surface }+ \text { Water }+ \text { Quality }+ \text { Objectives.pdf } \& 1}$ =English

Saskatchewan Ministry of Energy and Resources. 2008. Saskatchewan's Ultimate Potential for Conventional Natural Gas, Miscellaneous Report 2008-8. http://www.neb.gc.ca/clfnsi/rnrgynfmtn/nrgyrprt/ntrlgs/ssktchwnltmtptnt12008/ssktchwnltmtptnt12008-eng.pdf 
Saskatchewan Water Authority. 2008. Buffalo Pound Dam, http://www.swa.ca/Publications/Documents/FS-310.pdf.

Saskatchewan Water Authority, http://www.swa.ca/WaterManagement/DamsAndReservoirs.asp\#

Schlumberger. 2009. Unpublished report number 09-DC-0047-C, prepared for the Petroleum Technology Research Centre, May 2009.

Sipple, M., S. Zinke, G. Magruder and D. Eby. 1995. Improved Recovery Demonstration for Williston Basin Carbonates, Annual Report for the Period June 10, 1994 to June 9, 1995. DOE/BC/14984-5 (DE95000186), Distribution Category UC-122. September 1995.

Sorrensen, J.A., T.P. Bailey, S.A. Smith, C.D. Gorecki, D.W. Fischer, W.D. Peck, E.N. Steadman and J.A. Harju. 2009. $\mathrm{CO}_{2}$ Storage Capacity Estimates for Stacked BrineSaturated Formations in the North Dakota Portion of the Williston Basin, Energy Procedia 1. pp. 2833-2840.

Trail Canada, http://www.trailcanada.com/canada/weather/

Underwood, E.C., G.A. Ferguson, R. Betcher and G. Phipps. 2009. Elevated Ba Concentrations in a Sandstone Aquifer. Journal of Hydrology. 376, pp. 126-131. July 2009.

Vigrass, L., A. Jessop and B. Brunskill. 2007. Regina Geothermal Project, in Summary of Investigations 2007, Volume 1, Saskatchewan Geological Survey, Sask. Industry Resources, Misc. Rep. 2007-4.1, CD-ROM, Paper A-2, 21 p.

Whittaker, S., K. Worth and C. Preston. 2009. Aquistore: $\mathrm{CO}_{2}$ Storage in Deep Brines in Saskatchewan Canada, IFP, Ruesll-Malmaison, France, May 27-29 2009.

Williston Basin TGI, http://www.gov.mb.ca/stem/mrd/geo/willistontgi/maps.html\#list

Wittrup, M.B. 1988. The Origin of Water Leaks in Saskatchewan Potash Mines, M.S. Thesis in Geology, University of Saskatchewan.

Zeidouni, M., M. Pooladi-Darvish and M.W. Keith. 2010. Leakage Detection and Characterization through Pressure Monitoring, Energy Procedia, https://webdisk.ucalgary.ca/ mzeidoun/public html/Papers/Leakage Characteization_GHGT1 $\underline{0 . p d f}$ 


\section{List of Acronyms}

$\begin{array}{ll}\text { amsl } & \text { Above mean sea level } \\ \text { BEG } & \text { Bureau of Economic Geology } \\ \text { BLR } & \text { Brine Leakage Risk } \\ \text { CF } & \text { Certification Framework } \\ \text { CLR } & \text { CO }_{2} \text { Leakage Risk } \\ \text { CMG-GEM } & \text { Computer Modeling Group - Generalized Equation-of-State Model } \\ \text { DOE } & \text { U.S. Department of Energy } \\ \text { ECA } & \text { Emissions Credit and Atmosphere } \\ \text { EMI } & \text { Electrical Micro Imaging } \\ \text { EPA } & \text { Environmental Protection Agency } \\ \text { GCS } & \text { Geologic Carbon Sequestration } \\ \text { GEM } & \text { Generalized Equation of state Model } \\ \text { HMR } & \text { Hydrocarbon and Mineral Resources } \\ \text { HS } & \text { Health and Safety } \\ \text { LBNL } & \text { Lawrence Berkeley National Laboratory } \\ \text { UT } & \text { The University of Texas at Austin } \\ \text { Mt } & \text { Million tonnes (109 kg) } \\ \text { NSE } & \text { Near-surface environment } \\ \text { PTRC } & \text { Petroleum Technology Research Centre } \\ \text { SDTC } & \text { Sustainable Development Technology Canada } \\ \text { SGR } & \text { Shale Gouge Ratio } \\ \text { TD } & \text { Total Depth } \\ \text { TDS } & \text { Total Dissolved Solids } \\ \text { TGI } & \text { Targeted Geoscience Initiative } \\ \text { USDW } & \text { Underground Source of Drinking Water }\end{array}$




\section{Appendix A. CF Definitions and Methods}

\subsection{Overview}

The purpose of the $\mathrm{CF}$ is to provide a framework for project proponents, regulators, and the public to analyze the risks of geologic $\mathrm{CO}_{2}$ storage in a simple and transparent way to certify startup and decommissioning of geologic $\mathrm{CO}_{2}$ storage sites. The $\mathrm{CF}$ currently emphasizes leakage risk associated with subsurface processes and excludes compression, transportation, and injection-well leakage risk. The CF is designed to be simple by (1) using proxy concentrations or fluxes for quantifying impact rather than complicated exposure functions, (2) using a catalog of pre-computed $\mathrm{CO}_{2}$ injection results, and (3) using a simple framework for calculating leakage risk. For transparency, the $\mathrm{CF}$ endeavors to be clear and precise in terminology in order to communicate to the full spectrum of stakeholders. Definitions are presented in the next section, followed by brief description of the framework structure.

\subsection{Definitions}

- Effective Trapping is the proposed overarching requirement for safety and effectiveness.

- Storage Region is the 3D volume of the subsurface intended to contain injected $\mathrm{CO}_{2}$.

- Leakage is migration across the boundary of the Storage Region.

- Compartment is a region containing vulnerable entities (e.g., environment and resources).

- Impact is a consequence to a compartment, evaluated by proxy concentrations or fluxes.

- Risk is the product of probability and consequence (impact).

- $\mathrm{CO}_{2}$ Leakage Risk is the probability that negative impacts will occur to compartments due to $\mathrm{CO}_{2}$ migration.

- Effective Trapping implies that $\mathrm{CO}_{2}$ Leakage Risk is below agreed-upon thresholds.

\subsection{Compartments and Conduits}

In the $\mathrm{CF}$, impacts occur to compartments, while wells and faults are the potential leakage pathways. Figure A-1 shows how the CF conceptualizes the system into source, conduits (wells and faults), and compartments HMR, USDW, NSE, HS, and ECA, where

- $\mathrm{ECA}=$ Emission Credits and Atmosphere

- $\mathrm{HS}=$ Health and Safety

- NSE = Near-Surface Environment

- $\mathrm{USDW}=$ Underground Source of Drinking Water

- $\mathrm{HMR}=$ Hydrocarbon, and Mineral Resource

\subsection{Risk and Flow Chart}

Figure A-2 shows the concepts of likelihood of the $\mathrm{CO}_{2}$ source intersecting conduits, and the conduits having likelihood of intersecting compartments. In the $\mathrm{CF}$, the probability of $\mathrm{CO}_{2}$ leaking from the source to a compartment is the product of the two intersection probabilities. 
Figure A-3 shows a flow chart of CF logic and inputs and outputs. Table A.1 shows the general steps taken in a CF analysis.

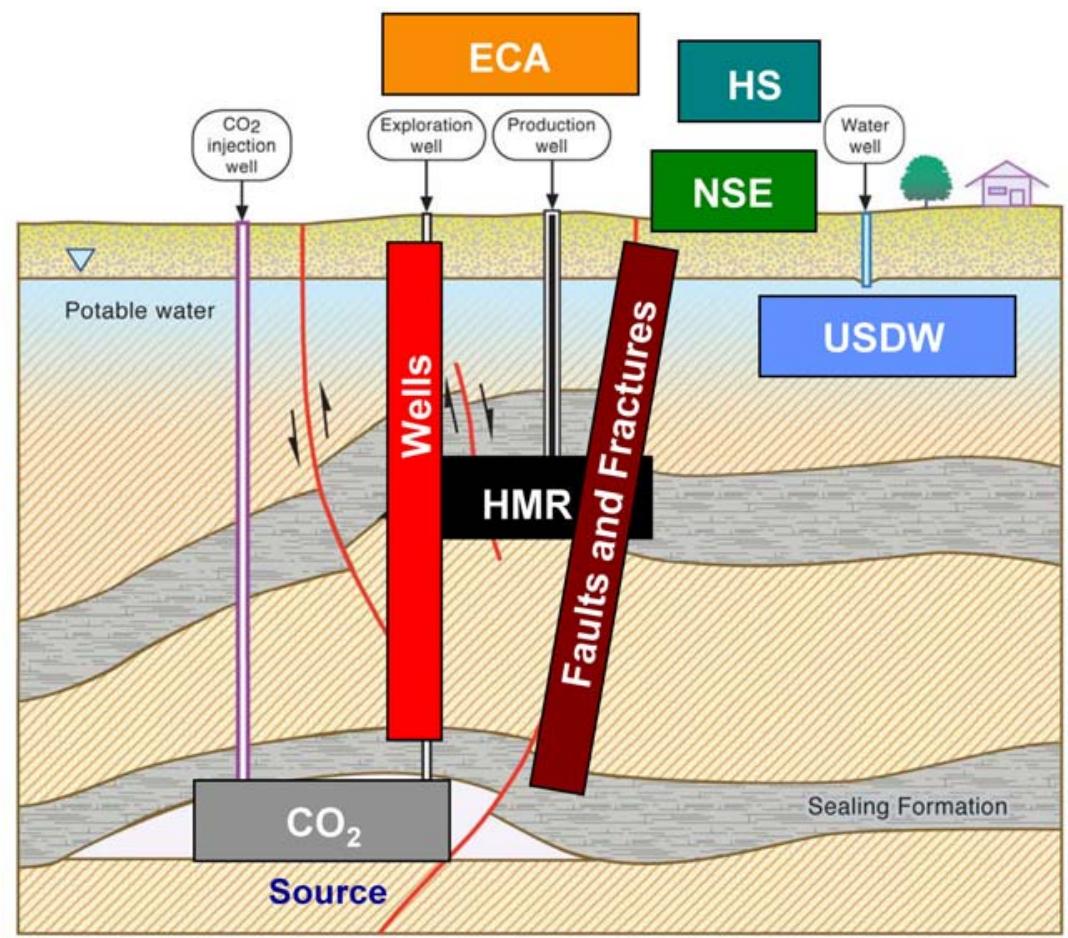

Figure A-1. Generic schematic of compartments and conduits in the CF.

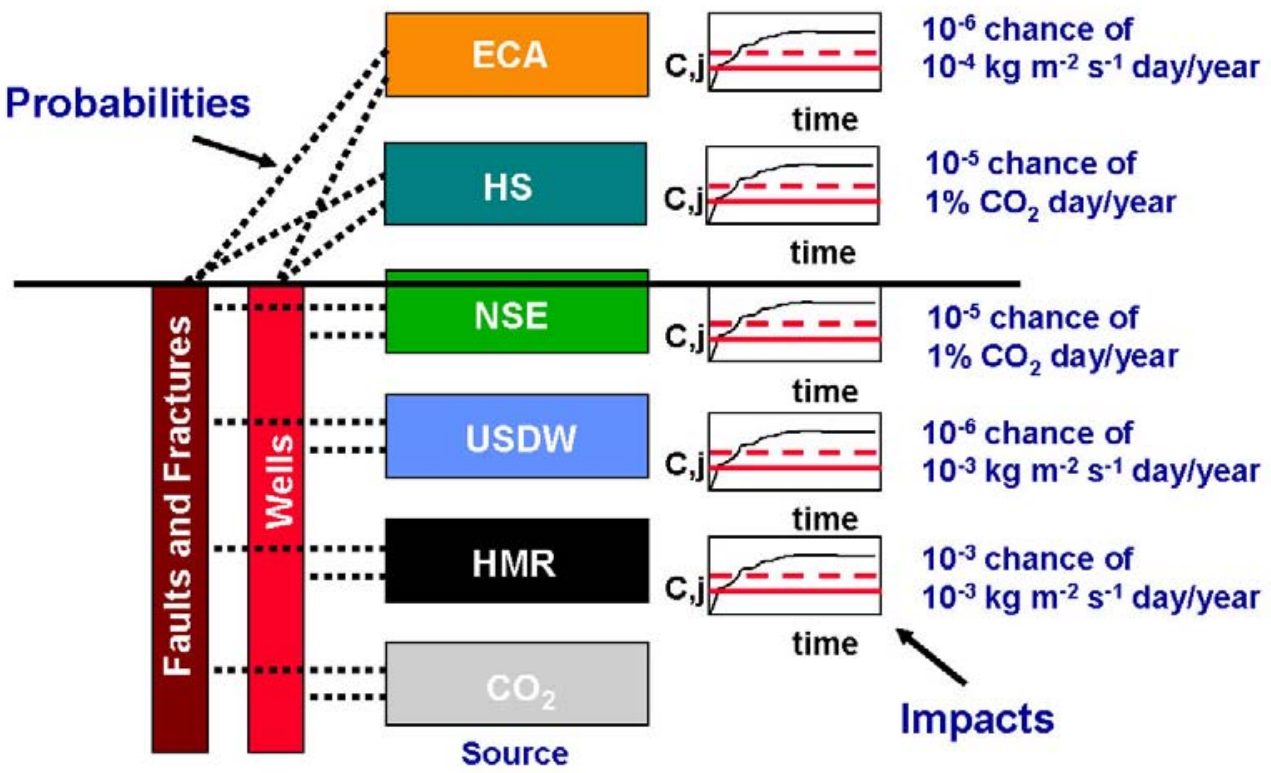

Figure A-2. $\mathrm{CO}_{2}$ leakage risk schematic. 


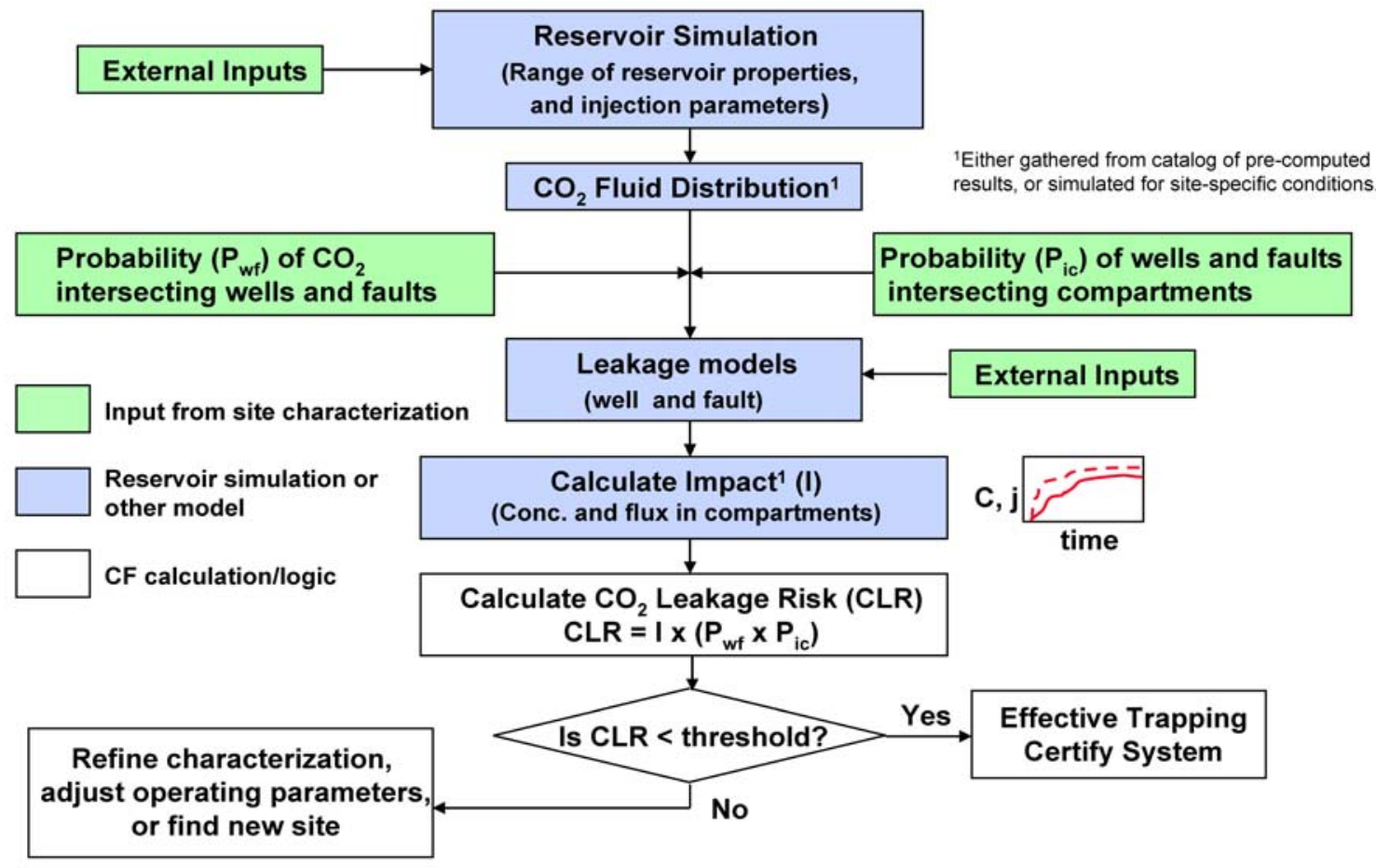

Figure A-3. Flow chart of CF process showing logic and inputs and outputs. 
Table A.1. Tasks and Steps in the CF approach.

\begin{tabular}{|c|c|c|c|}
\hline Task & Step & Name & Description \\
\hline \multirow{3}{*}{1} & 1 & Project definition & $\begin{array}{l}\text { Gather information on location, injection depth, } \\
\text { properties of the formation, injection rate, number of } \\
\text { wells, duration of injection, etc. }\end{array}$ \\
\hline & 2 & Define storage region & $\begin{array}{l}\text { Supplement the project definition with a practical and } \\
\text { acceptable definition of the boundaries of the storage } \\
\text { region. }\end{array}$ \\
\hline & 3 & $\begin{array}{l}\text { Identify } \\
\text { vulnerabilities }\end{array}$ & $\begin{array}{l}\text { E.g., wells and faults are potential leakage pathways; } \\
\text { hydrocarbon and mineral resources, potable } \\
\text { groundwater, near-surface environment, health and } \\
\text { safety, and the atmosphere are potentially vulnerable } \\
\text { entities that are grouped into "compartments" in the } \\
\text { CF. }\end{array}$ \\
\hline 2 & 4 & $\begin{array}{l}\text { Characterize } \\
\text { vulnerabilities }\end{array}$ & $\begin{array}{l}\text { Determine properties of wells, faults, cap rock to the } \\
\text { extent possible; determine properties of the } \\
\text { compartments in which impacts may occur. }\end{array}$ \\
\hline \multirow{3}{*}{3} & 5 & $\begin{array}{l}\text { Injection and } \\
\text { migration modeling }\end{array}$ & $\begin{array}{l}\text { Simulate injection and migration of } \mathrm{CO}_{2} \text { and brine } \\
\text { pressurization (or use catalog or other existing results) } \\
\text { to estimate sizes of } \mathrm{CO}_{2} \text { plume and pressure } \\
\text { perturbation. }\end{array}$ \\
\hline & 6 & $\begin{array}{l}\text { Estimate likelihood } \\
\text { of leakage }\end{array}$ & $\begin{array}{l}\text { From simulation results and spatial characterization of } \\
\text { leakage conduits, estimate probability of leakage. }\end{array}$ \\
\hline & 7 & $\begin{array}{l}\text { Model impacts of } \\
\text { leakage }\end{array}$ & $\begin{array}{l}\text { Use specialized models in the CF to calculate fluxes or } \\
\text { concentrations in the compartments as a function of } \\
\text { time. }\end{array}$ \\
\hline 4 & 8 & Risk calculation & $\begin{array}{l}\text { Calculate } \mathrm{CO}_{2} \text { Leakage Risk (CLR) and Brine Leakage } \\
\text { Risk (BLR) }(\mathrm{CLR}=\text { likelihood of leakage } \mathrm{x} \text { impact of } \\
\text { leakage) }\end{array}$ \\
\hline
\end{tabular}




\section{DISCLAIMER}

This document was prepared as an account of work sponsored by the United States Government. While this document is believed to contain correct information, neither the United States Government nor any agency thereof, nor The Regents of the University of California, nor any of their employees, makes any warranty, express or implied, or assumes any legal responsibility for the accuracy, completeness, or usefulness of any information, apparatus, product, or process disclosed, or represents that its use would not infringe privately owned rights. Reference herein to any specific commercial product, process, or service by its trade name, trademark, manufacturer, or otherwise, does not necessarily constitute or imply its endorsement, recommendation, or favoring by the United States Government or any agency thereof, or The Regents of the University of California. The views and opinions of authors expressed herein do not necessarily state or reflect those of the United States Government or any agency thereof or The Regents of the University of California.

Ernest Orlando Lawrence Berkeley National Laboratory is an equal opportunity employer. 